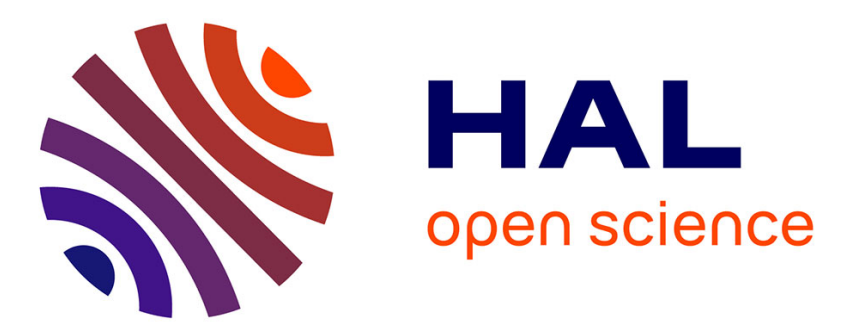

\title{
Immune-modulators to combat hepatitis B virus infection: From IFN- $\alpha$ to novel investigational immunotherapeutic strategies
}

Nathalie Isorce, Julie Lucifora, Fabien Zoulim, David Durantel

\section{- To cite this version:}

Nathalie Isorce, Julie Lucifora, Fabien Zoulim, David Durantel. Immune-modulators to combat hepatitis B virus infection: From IFN- $\alpha$ to novel investigational immunotherapeutic strategies. Antiviral Research, 2015, 122, pp.69 - 81. 10.1016/j.antiviral.2015.08.008 . hal-03319419

\author{
HAL Id: hal-03319419 \\ https://hal.science/hal-03319419
}

Submitted on 12 Aug 2021

HAL is a multi-disciplinary open access archive for the deposit and dissemination of scientific research documents, whether they are published or not. The documents may come from teaching and research institutions in France or abroad, or from public or private research centers.
L'archive ouverte pluridisciplinaire $\mathbf{H A L}$, est destinée au dépôt et à la diffusion de documents scientifiques de niveau recherche, publiés ou non, émanant des établissements d'enseignement et de recherche français ou étrangers, des laboratoires publics ou privés. 


\section{Accepted Manuscript}

Review

Immune-modulators to combat hepatitis B virus infection: from IFN- $\alpha$ to novel investigational immunotherapeutic strategies

Nathalie Isorce, Julie Lucifora, Fabien Zoulim, David Durantel

PII:

S0166-3542(15)00194-1

DOI: http://dx.doi.org/10.1016/j.antiviral.2015.08.008

Reference: AVR 3678

To appear in:

Antiviral Research

Received Date:

16 July 2015

Accepted Date:

11 August 2015

Please cite this article as: Isorce, N., Lucifora, J., Zoulim, F., Durantel, D., Immune-modulators to combat hepatitis B virus infection: from IFN- $\alpha$ to novel investigational immunotherapeutic strategies, Antiviral Research (2015), doi: http://dx.doi.org/10.1016/j.antiviral.2015.08.008

This is a PDF file of an unedited manuscript that has been accepted for publication. As a service to our customers we are providing this early version of the manuscript. The manuscript will undergo copyediting, typesetting, and review of the resulting proof before it is published in its final form. Please note that during the production process errors may be discovered which could affect the content, and all legal disclaimers that apply to the journal pertain. 


\section{Immune-modulators to combat hepatitis B virus infection: from IFN- $\alpha$ to novel investigational immunotherapeutic strategies}

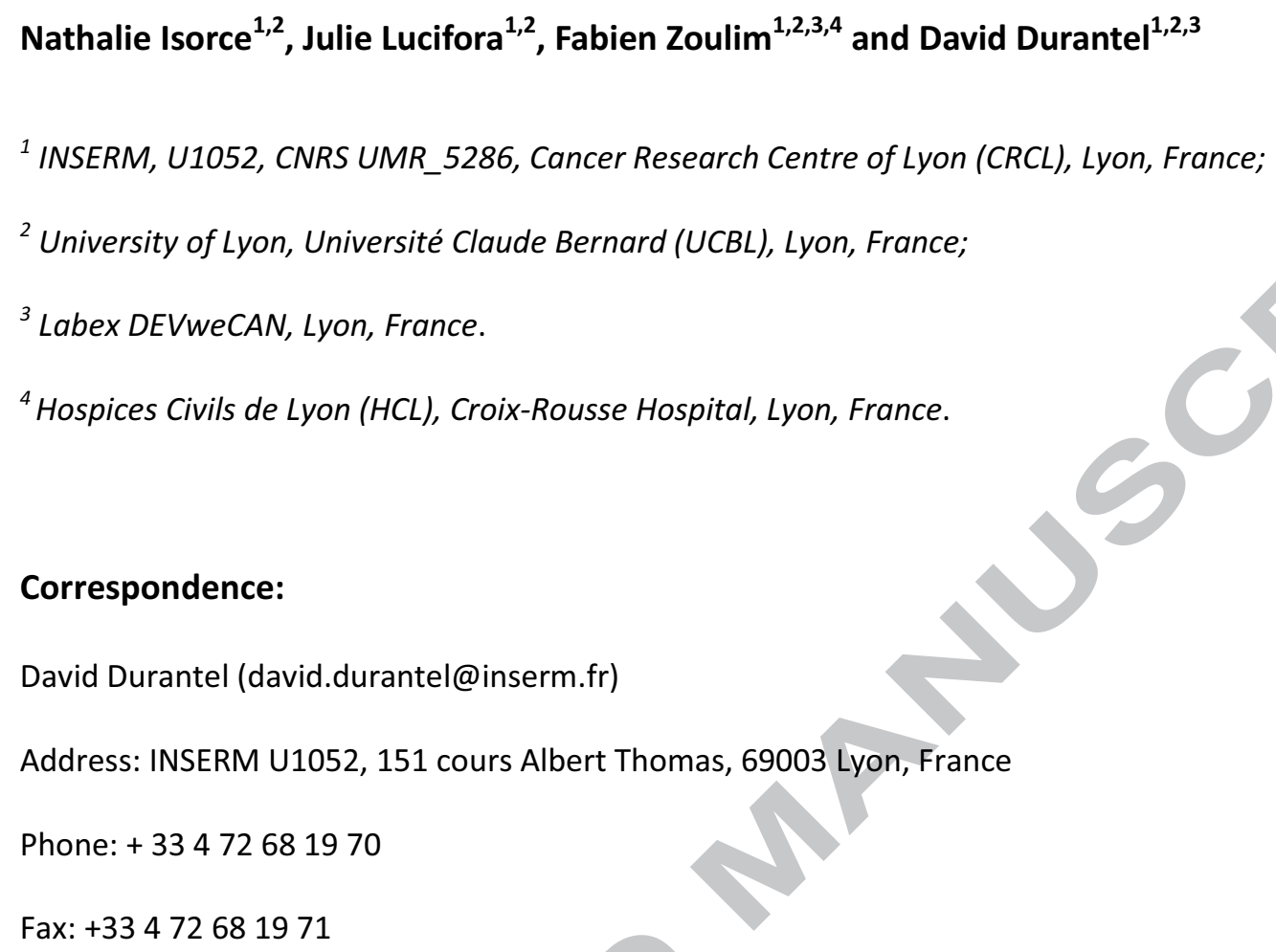




\section{Abstract:}

Chronic hepatitis B virus (HBV) infection remains a major challenge for clinicians, as there are only two types of approved therapies: interferon-alpha (IFN- $\alpha$ ) or its pegylated form, Peg-IFN- $\alpha$ and nucleoside analogues (e.g. tenofovir, entecavir...). The first are used as finite-duration treatments of around 48-52 weeks, while the second must be taken life-long to prevent rebound. Other immune-modulators, including other types of recombinant IFNs and cytokines/chemokines, could be developed for treating chronic hepatitis B. Alternatively, strategies aimed either at restoring or favouring the endogenous production of IFNs, cytokines and/or chemokines, or at alleviating HBV-mediated inhibitory processes could also be envisaged. In this article, we review current investigational, preclinical and clinical efforts to implement immune-modulatory components in the therapy of chronic hepatitis B. This review forms part of a symposium in Antiviral Research on "An unfinished story: from the discovery of the Australia antigen to the development of new curative therapies for hepatitis B." 


\section{Introduction}

Chronic hepatitis B virus (HBV) infection remains a major challenge for clinicians, as there are only two types of approved therapies: interferon-alpha (IFN- $\alpha$ ) or its pegylated form, Peg-IFN- $\alpha$, and nucleoside analogues (e.g. tenofovir, entecavir...). The first are used as finite-duration treatments of around 48-52 weeks, while the second must be taken life-long to prevent rebound. In this article, we review current investigational, preclinical and clinical efforts to improve the therapy of chronic hepatitis B by implementing novel immune-modulatory components. As listed in Tables 1 and 2, these approaches include new IFNs and other recombinant cytokines/chemokines, which have been tested mainly as adjuvant components in vitro, in animal models or/and in human trials in the context of various chronic viral infections. We also discuss new strategies aimed either at restoring or favouring the endogenous production of IFNs, cytokines and/or chemokines, or at alleviating HBV-mediated inhibitory processes.

\section{Background: Interferons, cytokines and chemokines}

Cytokines/chemokines are soluble substances, in general polypeptides, glycosylated or not, with rather low molecular weights, which are secreted mainly by professional immune cells, but also by non-immune cells (e.g. epithelial and endothelial cells exposed to a virus) upon an exogenous or endogenous stimulus (Leonard, 2013; Murphy, 2013). Major stimuli of cytokines/chemokines production are pathogens, including viruses. Cytokines/chemokines signal to target cells after binding to specific/cognate receptors and triggering downstream signaling pathways, which lead to gene expression modulation and synthesis of effector proteins bearing biological activities, including antiviral activities. Cytokines/chemokines can be produced during acute infections with many viruses, and help mounting an innate and adaptive immune response to eliminate them (Iwasaki and Medzhitov, 2013). They can also be produced during chronic phases of infection, and in this case are not much involved in the inhibition of viral replication, but instead contribute to immune-pathogenesis. The latter has been suggested for chronic hepatitis $\mathrm{C}$ virus (HCV) infections, human immunodeficiency virus (HIV) infections, and even more significantly for co-infections with both viruses (Chen et al., 2014; Snell and Brooks, 2015; Szabo and Petrasek, 2015). 
The first cytokines to be described in 1957 were interferons (Issacs and Lindenmann, 1957a, b), a

large family of low-molecular weight (15-30 kDa), soluble glycoproteins with potent antiviral activities. IFNs are now classified into three different categories, according to the structure of their receptors, called type-I, II and III (Sadler and Williams, 2008; Samuel, 2001). Type-I IFNs consist of at least 18 members: 14 highly homologous IFN- $\alpha$ subtypes encoded by different non allelic genes, the well-known IFN- $\beta$ encoded by a unique gene, and others, which have not been so far intensively studied, including IFN- $\varepsilon$, IFN- $\omega$, and IFN-א. Whereas IFN- $\beta$ can be virtually produced by all nucleated cells exposed to viruses or other IFN-inducing pathogens, IFN- $\alpha$ are mainly produced by one particular type of immune cells, the plasmacytoid dendritic cells (pDC) (Reizis et al., 2011).

All type-I IFNs bind and signal through the same receptor, called IFN- $\alpha$ R (IFNAR), and composed of two subunits: IFN- $\alpha$ R1 and IFN- $\alpha$ R2 (Sadler and Williams, 2008; Samuel, 2001). This receptor is widely expressed at the surface of cells, which is an advantage when it comes to endogenous systemic protection, but an inconvenient for a systemic use of exogenous recombinant type-I IFNs, as it can lead to toxicity. TypeII IFNs consist only of IFN- $\gamma$, are mainly expressed by immune cells, including natural killer (NK), T and NKT cells, and signal through the IFN- $\gamma \mathrm{R}$ receptor, which is composed of two heterodimers of IFN- $\gamma \mathrm{R} 1$ and IFN$\gamma$ R2 and is widely expressed at the surface of cells (Sadler and Williams, 2008; Samuel, 2001). Type-III IFNs consist of 4 different members, IFN- $\lambda 1$ (also known as IL-29), IFN- $\lambda 2$ (IL-28A), IFN- $\lambda 3$ (IL-28B), and the only very recently identified IFN- $\lambda 4$ (Egli et al., 2014). IFN- $\lambda$ s can be produced by many epithelial cells, including hepatocytes, but are mainly produced by immune cells. Amongst dendritic cells (DCs), the main producer type would be the myeloid DC-BDCA3(+)/CLEC9A(+) cells (van der Aa et al., 2015). IFN- $\lambda$ s signal through a specific heterodimeric receptor (IFN- $\lambda$ R), composed of IL-10RB and IL-28RA (or IFN- $\lambda$ R1) subunits (Sadler and Williams, 2008; Samuel, 2001), which is not widely expressed as compared to IFN- $\alpha$ R and IFN- $\gamma R$ receptors. Indeed, this receptor is mainly expressed in epithelial cells (e.g. hepatocytes). This particularity has attracted a lot of interest for this type of IFNs in the field of hepatotropic viruses.

IFNs have been very useful immune-modulators to fight chronic infections, including hepatitis C, B, and delta (Ciancio and Rizzetto, 2014; Lin and Young, 2014). Indeed a pegylated form of IFN- $\alpha$, Peg-IFN- $\alpha$, combined with ribavirin (RBV), has represented the standard of care (SOC) to fight HCV chronic infections 
during the last two decades, and is yet playing an important role in low-income countries (Feld, 2014). Indeed if developed-countries have entered into an IFN-free era in terms of therapeutic practice, the cost of DAA (direct acting agents) treatments, is yet non-affordable in many countries. For hepatitis delta virus (HDV) infections, Peg-IFN- $\alpha$ remains the sole therapeutic option, combined with nucleoside analogues to induce HBV viro-suppression (Ciancio and Rizzetto, 2014). IFNs have taken the lead as therapeutic antiviral agents over other cytokines due to the early development of techniques to produce and purify them as injectable recombinant molecules. However, only few IFNs, amongst which IFN- $\alpha 2 a$, IFN- $\alpha 2 b$, consensus IFN- $\alpha$, IFN- $\beta$, IFN- $\gamma$, IL-29, have been produced and tested in clinical trials against chronic viral infections or other indications (Ciancio and Rizzetto, 2014; Lin and Young, 2014; Zitvogel et al., 2015). It is therefore likely that other IFNs could be useful therapeutic options as antiviral and anticancer agents.

\section{Interferon- $\alpha$ for the treatment of chronic hepatitis B}

Regimens containing IFN- $\alpha$ remain a front-line therapy in many countries (Table 1 ), despite the fact that it has many adverse effects. It represents the sole treatment with a finite duration for CHB patients, as compared to NUC.

\subsection{Treatment indications}

The goal of therapy for CHB is to improve the quality of life and survival by preventing or significantly delaying progression of the disease toward end-stage liver disease and hepatocellular carcinoma (HCC). This goal can be achieved if HBV replication is suppressed in a sustained manner, leading to a reduction in histological activity of CHB and decreased risk of developing cirrhosis and HCC (EASL, 2012; Zoulim and Durantel, 2015).

The natural history of $\mathrm{CHB}$ is rather complex, with 4 different phases that can occur during the course of infection, including the i) "immune-tolerant", ii) immune active/HBeAg(+) chronic hepatitis, iii) immune active/HBeAg(-) chronic hepatitis, and iv) “inactive carrier” phases (Gish et al., 2015; McMahon, 2014). Treatment is not indicated in all phases of CHB. The international clinical practice guidelines recommend that $\mathrm{CHB}$ patients, which can either be $\mathrm{HBeAg}(+)$ or $\mathrm{HBeAg}(-)$, should be considered for treatment when they have HBV DNA levels above 2,000 IU/ml, serum alanine aminotransferase (ALT) levels 
above the upper limit of normal (ULN), and moderate to severe active necro-inflammation and/or at least moderate liver fibrosis severity (EASL, 2012; Zoulim and Durantel, 2015).

\subsection{IFN- $\alpha$ therapy in $\mathrm{HBeAg}(+)$ and (-) patients}

In current practice, Peg-IFN- $\alpha(180 \mu \mathrm{g})$ is weekly administered for $48-52$ weeks in $\mathrm{HBeAg}(+)$ patients to increase rate of $\mathrm{HBeAg}$ to anti-HBeAg (HBeAc) seroconversion at the end of treatment (Lau et al., 2005; Marcellin et al., 2004). During treatment, patients become undetectable for HBV in serum in only $25 \%$ of cases, which is far lower than that achieved with either entecavir ( $\approx 65 \%$ ) (Kang et al., 2007) or tenofovir $(\approx 75 \%)$ (Marcellin et al., 2008). But the rate of HBeAg seroconversion post-treatment is at around $30 \%$, which is higher than that achieved by NUC (e.g. ETV or TFV). The normalization of ALT is observed in 30 to $40 \%$ of cases, which is well in phase with the seroconversion rate. As for NUC therapies, the rate for $\mathrm{HBsAg}$ to anti-HBs seroconversion is very low for Peg-IFN therapy (i.e. $\approx 3 \%)$. Of course this means that they are few patients that are significantly capable to "immunologically control" HBV in the long term, and this is a strong rational to develop new therapies. Regarding $\mathrm{HBeAg}(-) \mathrm{CHB}$ patients, if the performance of Peg-IFN in term of viro-suppression is higher (around 60\% of HBV DNA negativation on treatment), the ALT normalization and $\mathrm{HBs}$ seroconversion are no better than for $\mathrm{HBeAg}(+)$ patients.

One major drawback of IFN therapy comes from the frequent, numerous, and sometime severe, adverse effects experienced by patients (EASL, 2012; Zoulim and Durantel, 2015). Common side effects of IFN include flu-like symptoms following each injection such as fever, headache, muscle aches, pains (articulation, abdominal, back...). These side effects vary from mild to severe and occur in up to half of all patients. The symptoms tend to diminish with repeated injections and may be managed with analgesics and antihistamines. Other important side effects include: general fatigue, gastrointestinal disorders, thrombocytopenia, neutropenia, and depression episode that can be very severe and lead to suicidal behavior.

\subsection{Combinations of Peg-IFN and NUC}

One of the major questions regarding antiviral therapy of $\mathrm{CHB}$, was whether the combination of Peg-IFN- $\alpha$ with NUC could improve the rate of off-treatment response and HBsAg seroconversion and shorten treatment duration. Despite the observation that combination of Peg-IFN- $\alpha$ with lamivudine (LMV) or 
telbivudine (LdT) showed a higher on-treatment virological response, combination did not show a higher rate of sustained off-treatment virological or serological response (Janssen et al., 2005; Lau et al., 2005; Marcellin et al., 2004). Several studies are ongoing with the combination of Peg-IFN- $\alpha$ and ETV or TFV (Kao, 2014), but currently these types of combination are not yet recommended for CHB. Furthermore, there are no data to indicate an advantage of de novo combination with ETV and TFV in NUC-naive patients, although more studies in patients with high baseline viremia (HBV DNA $>10^{8} \mathrm{IU} / \mathrm{mL}$ ) are required.

In contrast to CHB patients, patients chronically infected by both HBV and HDV need to be treated with Peg-IFN- $\alpha$ plus a NUC. The results of recent clinical trials have been recently disclosed and provide a good framework for clinical managements (Heidrich et al., 2014; Wedemeyer et al., 2011).

\subsection{Modes of action of IFN- $\alpha$}

There are two main modes of action (MOAs) for exogenously administered IFN- $\alpha$, explaining its broad antiviral activities (Table 2). IFN- $\alpha$ can induce in a receptor-specific manner the expression of genes encoding intracellular or secreted effector proteins. On the one hand, these effectors bear antiviral properties and can act within infected to help eliminating the virus, as well as non-infected cells to protect them against infection. On the other hand, they promote the differentiation/activation of immune cells (Sadler and Williams, 2008; Samuel, 2001).

IFN- $\alpha$ binds to the IFNAR receptor and activates the JAK/STAT pathway, which leads to the transcription of a particular set of genes called interferon-stimulated genes (ISGs) via the action of the phosphorylated hetero-trimeric transcription factor ISGF3 (composed of pSTAT1, pSTAT2 and IRF9) (Figure 1). The promoters of ISGs contain one or several "interferon-stimulated response element" (ISRE motifs), which are the sites of binding of ISGF3 complexes. There are hundreds of ISGs (Sadler and Williams, 2008), but the exhaustive subsets of the ones that may lead to anti-HBV effect within infected cells are far from being identified. The analysis of the implication of ISGs in an anti-HBV phenotype in vitro is rendered difficult by the fact that IFN- $\alpha$ is a not a very potent inhibitor of HBV replication in relevant cell culture models, including primary human hepatocytes $(\mathrm{PHH})$ and the HepaRG cell line. Those models are relevant because there are functional for innate functions in contrast to hepatoma cells (Luangsay et al., 2015). In our hands, only a $50 \%$ reduction of the intracellular total HBV DNA accumulation is observed with a single 
and high (i.e not physiologic; $1000 \mathrm{IU} / \mathrm{mL}$ ) dosing of IFN- $\alpha$ (Isorce et al., submitted; AVR-S-15-00187).

Moreover, in these cell types, it is not technically easy to either over-express ISGs or down-regulate their expression in gain and loss of function studies. Hence, ISGs proteins responsible for the antiviral effect mediated by IFN- $\alpha$ have not yet been firmly identified. The ones that have been pointed out as potentially involved, i.e. MxA, ZAP, APOBEC3G (Gordien et al., 2001; Mao et al., 2013; Nguyen et al., 2007), following experiments in transfection, have yet to be confirmed. Nevertheless it has been shown that IFN- $\alpha$ would be capable to restrict HBV replication by preventing encapsidation of genome, by inducing RNA degradation, and by silencing cccDNA through epigenetic regulation (Belloni et al., 2012; Rang et al., 1999; Wieland et al., 2000). More strikingly, it was recently found, using relevant cell culture models (i.e. PHH and HepaRG), in which cccDNA is formed and physiologically regulated, that IFN- $\alpha$ treatment could induce the degradation of ccCDNA via an APOBEC3A-mediated deamination mechanism (Lucifora et al., 2014; Xia et al., 2014).

IFN- $\alpha$ is also known to promote the differentiation/activation of immune cells, which play an important role in clearing viral infections (Crouse et al., 2015). Amongst important cells that are positively regulated by IFN $\alpha$ are $\mathrm{pDC}, \mathrm{mDC}, \mathrm{NK} / \mathrm{NKT}$, and T cells. The problem in the context of CHB is that immune responses are impaired by the virus itself, notably by the induction of T-reg, cell exhaustion, and removal of HBV-specific T cells (Koh and Bertoletti, 2015). A treatment with exogenous IFN- $\alpha$ is often not sufficient enough to restore an appropriate response to the virus. In a recent and elegant study, it was shown that IFN- $\alpha$ could boost NK/NKT cells functions in CHB patients, but that in turn these boosted NK/NKT cells were responsible for the destruction of $\mathrm{CD}^{+}{ }^{+}$cells via a TRAIL-mediated mechanism (Micco et al., 2013). As long term NUC treatments are associated with restoration of T cell functions in CHB patients, it gives a strong rational to revisit combination therapy associating IFN- $\alpha$ with a NUC (Thimme and Dandri, 2013). In this respect the use of the recently developed liver-humanized mouse models can be useful for pre-clinical studies (Allweiss et al., 2014).

\section{Other IFNs for the treatment of HBV infections}

\subsection{Other Type-I IFNs}


Due to the numerous side effects and the fact that currently used IFN- $\alpha$ (i.e. IFN- $\alpha 2$ a and IFN- $\alpha 2$ b) may not

be adapted to all patients, because of population genetic diversity of ligand/receptor systems, others IFNs have been considered for therapeutic use. Many other subtypes of IFN- $\alpha$ or formulations have been evaluated in particular for their effect against the replication of the hepatitis C virus, another hepatotropic virus (Table 1). When IFN- $\alpha$ is naturally produced by human leucocytes, it consists of a mixture of many subtypes (up to 14). This is the principle of Alferon-N (IFN- $\alpha n-3)$, which is used for the treatment of genital warts caused by human papillomavirus (HPV). But the manufacturing process to produce this IFN is only compatible with local and not systemic injection; this could explain why this IFN was not extensively tested in other indications. Alternatively clonally-produced other subtypes of IFN- $\alpha$ have been tested for their antiviral properties, and it was found that IFN- $\alpha 17$ was particularly efficient in vitro against HCV (Escuret et al., 2006); this suggest the relevance of considering a tailored use of various IFN- $\alpha$ subtypes for a given indication. But the main problem is that converting this into clinically usable drugs is beyond feasibility. An interesting alternative approach was to generate a consensus interferon (CIFN or IFN- $\alpha$ con1; InterMune) by using the most commonly observed amino acids amongst all IFN- $\alpha$ subtypes at each position. In vitro CIFN has demonstrated a 10- to 100-fold increase in antiviral activity, as compared to other recombinant IFN- $\alpha$ (Ozes et al., 1992), thus enabling weaker dosing and reduced toxicity. In the context of HCV infections, it was shown in particular that retreatment of full non-responders to Peg-IFN/RBV with CIFN (up to $15 \mu \mathrm{g}$ ) + RBV was safe and "efficacious" (up to $30 \%$ sustained virological response (SVR)) to some extend (Bacon et al., 2009).

The main problem with this approved drug is that, due to its short half-life, it has to be injected daily, which is not acceptable nowadays in clinical setting. The development of a long-life form of CIFN is necessary; in this respect a hyper-glycosylated form of CIFN has been recently shown to have a very extended life span in mouse, hence rendering possible a monthly or bimonthly dosing of the drug (Taylor et al., 2015). One could expect that initial interesting results, obtained in clinical trial with CIFN in CHB patients (Zheng et al., 2009), could be improved with a future novel formulation of the drug.

Modified IFN- $\alpha$, obtained by conjugation with moiety meant to stabilize or humanize the cytokine, have also been envisaged. Hence Peg-IFN- $\alpha 2 a$ (Pegasys; Hoffmann-La-Roche) and Peg-IFN- $\alpha 2 b$ (PegIntron; 
Schering Plough), which consist respectively of a single (40 kDa) or several (12 kDa) polyethylene-glycol (Peg) chain(s) added to IFN backbone are currently used to treat CHB patients (Foster, 2010). Other modification included the addition of human albumin moiety to IFN backbone to generate a long half-life fusion protein (albinterferon), which was evaluated in stage III clinical trial in the context of HCV infections and showed no superiority to Peg-IFN (Nelson et al., 2010; Subramanian et al., 2007; Zeuzem et al., 2010). Moreover, in the context of HBV infection, albinterferon has shown higher rates of certain adverse effect as compared to PegIFN- $\alpha$, thus likely limiting its further development (Colvin et al., 2015).

IFN- $\beta$, which uses the same cell-signaling receptor than IFN- $\alpha$, but with a greater affinity (Zitvogel et al., 2015), has been also considered as an alternative. IFN- $\beta$, and in particular its recently developed pegylated form, is already used for the treatment of multiple sclerosis, a chronic immune mediated disease (Khan et al., 2015). Studies proving the safety and efficiency as anti-HCV of either naturally produced or recombinant, non-pegylated form, of IFN- $\beta 1 \mathrm{a} / \mathrm{b}$ have been mainly performed in Asian countries (Lin and Young, 2014). If the pattern of toxicity looked more favorable than that with IFN- $\alpha$, further studies with a pegylated form (in combination with RBV for $\mathrm{CHC}$ patients) would be require to move forward regarding its potential use in CHB context. In vitro, it was early shown that recombinant IFN- $\beta$ could have a weak, yet comparable to IFN- $\alpha$, anti-HBV activity in the suboptimal HepG2.2.15 model (Caselmann et al., 1992). More recently, using the relevant HepaRG cell line model (Luangsay et al., 2015), we have shown that recombinant IFN- $\beta$ was slightly more potent than IFN- $\alpha$ at inhibiting HBV replication (Isorce et al., submitted; AVR-S-15-00187). The anti-HBV effect of IFN- $\beta$ was also investigated in an HBV-transgenic mouse model by direct injection of large amount of recombinant cytokine $(500,000$ unit/mouse) or by activation of endogenous production by another pathogen or TLR agonists HBV (Guidotti et al., 1996a; Guidotti et al., 1994; Isogawa et al., 2005; Pasquetto et al., 2000). Mechanistically, using the same model, or cells derived from their liver, it was shown that IFN- $\beta$ could induce the destabilization of pregenomic-RNA containing capsid within replicating cells, thus leading to a reduction of intracellular DNA production and viremia (Pasquetto et al., 2002; Wieland et al., 2000). However this transgenic model does not feature cccDNA, as HBV is transcribed from integrated genome; therefore it is not adapted to investigate strategies aiming at transcriptionally silence or degrade cccDNA. Using the same relevant models than that used by Lucifora and 
colleagues (Lucifora et al., 2014), it would be nice to investigate the details of the mode of action of IFN- $\beta$.

\subsection{Type-III IFNs - IFNs lambda}

Type-III IFNs represent a truly interesting therapeutic alternative to type-I IFNs, as the pattern of expression of their receptors (IFN- $\lambda$ R; i.e. heterodimer of IL-10RB and IFN- $\lambda$ R1/IL-28RA) is far more restricted than the ubiquitously-expressed IFNAR. Indeed IFN- $\lambda$ R, i.e. in particular the IFN- $\lambda$ R1 (or IL-28RA) subunit, is expressed mainly in cells of epithelial origin (e.g. hepatocytes, enterocytes, keratinocytes...), as well as in some immune cells, including lymphoid B/T cells and myeloid cells (macrophages, monocytes, DCs) (Egli et al., 2014); although in the latter the receptor would not be as functional as in epithelial cells (Lin and Young, 2014). In contrast, fibroblasts, endothelial, and most leucocyte cells do not express the full and functional receptor. This restricted pattern of expression is expected to positively impact on the toxicity profile of typeIII IFNs. Moreover, as for IFN- $\beta$ and in sharp contrast to IFN- $\alpha$, type-III IFN are not affected by IFN-induced refractoriness (Makowska et al., 2011). Refractoriness is defined by the lack of activation of the receptormediated signal transduction by repetitive and time closer exposure to its ligand. This theoretically, and in practice, limits the efficacy of IFN- $\alpha$ based therapy. Upon binding to their receptors, IFN- $\lambda$ s activate also the JAK-STAT transduction cascade leading to the formation and nuclear translocation of the ISGF3 (STAT1/STAT2/IRF9) transcription complex (Figure 1). The subset of genes induced by IFN $\lambda$ s is very similar to that induced by type-I IFNs, but the level of induction is thought to be in comparison weaker (Dumoutier et al., 2004).

Similar to type-1 IFN, it was shown that IFN- $\lambda$ s could inhibit the replication of HBV and HCV by inducing similar pattern of gene expression (Pagliaccetti et al., 2010; Robek et al., 2005). We have also studied the antiviral properties of IL-28B (IFN- $\lambda 3$ ) and IL-29 (IFN- $\lambda 1$ ) in HBV-infected HepaRG and PHH, and found that had almost similar effect as type-I IFNs, while displaying weaker toxicities (Isorce et al., submitted; AVR-S-15-00187). It is likely that type-III IFNs will also impact on the stability of cccDNA by an APOBEC3A-mediated MOA (Lucifora et al., 2014), but this remains to be firmly demonstrated using ad hoc models and kinetics of treatment allowing cccDNA degradation. If no direct injection of IFN- $\lambda$ s was attempted in HBV-infected liver-humanized mice, it was shown that targeted induction of these IFN- $\lambda \mathrm{s}$, by injection of hepatotropic cationic-liposome containing a synthetic double-stranded RNA analog poly $(\mathrm{I}: \mathrm{C})$ in 
the liver microenvironment, could lead to a strong HBV inhibitory phenotype in this animal model

(Nakagawa et al., 2013).

As for other IFNs, the development of an IFN- $\lambda$-based therapy for the treatment of CHB is lagging behind that of $\mathrm{CHC}$. In a phase-Ilb study performed on 526 treatment-naive $\mathrm{CHC}$ patients, it was found that Peg-IFN- $\lambda$ (between 120 and $240 \mu$; given weekly) + RBV (daily) achieved higher response rates, with fewer flu-like, musculoskeletal symptoms, and cytopenia/anemia, as compared to the previous standard of care (SOC; Peg-IFN- $\alpha+$ RBV) (Muir et al., 2014). Indeed Peg-IFN- $\lambda /$ RBV treatment led to respectively $56 \%$ of cEVR (complete early virologic response) as compared to $37 \%$ with Peg-IFN- $\alpha$ /RBV all genotypes confounded. The SVR (sustained virologic response) were comparable (37-46\%) between Peg-IFN- $\lambda /$ RBV and Peg-IFN- $\alpha$ /RBV for genotype 1 and 4, but were superior with Peg-IFN- $\lambda$ /RBV for genotype 2 and 3 (60$76 \%$ versus $53 \%$ with Peg-IFN- $\alpha$ /RBV). Results obtained in $\mathrm{CHC}$ patients should encourage investigator to perform clinical trials in CHB patients.

\subsection{Type-II IFN - IFN gamma (Table 1)}

IFN- $\gamma$ has a dimeric structure consisting of two polypeptides with antiparallel symmetry. It can bind to the IFN- $\gamma \mathrm{R}$, which is composed of two subunits: IFN- $\gamma \mathrm{R} 1$ and IFN- $\gamma \mathrm{R} 2$, and activate signal transduction cascades leading to the canonical nuclear translocation of the hetero-trimer ISGF3 transcription complex, as with type-I and III IFNs, but also the formation and nuclear translocation of a STAT1 homodimer (called GAF and composed of two phosphorylated STAT1), which binds in a cooperative manner to GAS elements present in the promoters of specific IFN- $\gamma$ inducible genes (Begitt et al., 2014) (Figure 1). The subsets of gene induced by type-I and type-II IFNs is largely overlapping, but some genes are better activated by IFN- $\gamma$, including for irf-1, cxcl-9, cxcl-10, adar-1, ido (Ahmed and Johnson, 2006; Begitt et al., 2014). Interestingly IRF-1, amongst ISG proteins, is thought to bear the broadest antiviral activity (Schoggins et al., 2011). IFN- $\gamma$ has of course "direct" antiviral activity against HCV and HBV, when applied to replicating hepatocytes in the absence of any immune cells. However, we found it to be the less active and most toxic of all IFNs tested in our HBVinfected HepaRG/PHH models (Isorce et al., submitted; AVR-S-15-00187).

Using the HBV transgenic model it was found that T-cell-produced IFN- $\gamma$ was very important to induce a non-cytopathic inhibition of HBV replication (Guidotti et al., 1996b). This inhibition could be 
recapitulated by administration of recombinant murine IFN- $\gamma$, and was dependent on IRF-1 and PKR in this model (Guidotti et al., 2002). The fact that IFN- $\gamma$ was capable to non-cytopathically induce HBV clearance, was confirmed in the even more relevant "chimpanzee model" of infection with HBV (Guidotti et al., 1999). Besides its action on the HBV pgRNA stability, encapsidation process, IFN- $\gamma$ would also be capable to induce cccDNA degradation by similar mechanisms than that featured by IFN- $\alpha$ (Xia et al., EASL 2015) (Table 2). The injection of recombinant IFN- $\gamma$ is approved for bacterial or fungal infection prophylaxis in patients suffering from chronic granulomatous disease, although the benefits appear limited (Smith and Denning, 2014). IFN- $\gamma$ therapy is also given to patients with profound defects in IFN- $\gamma$ and interleukin-12 production and seems to be beneficial for patients with invasive aspergillosis and cryptococcal meningitis. A high number of patients with chronic pulmonary aspergillosis are poor producers of IFN- $\gamma$ and could also benefit from IFN- $\gamma$ administration. As for its use in viral chronic diseases, IFN- $\gamma$ has not demonstrated, when injected alone, convincing efficacy against HIV, but is yet considered as a potential adjuvant for DNA-based therapeutic vaccination strategies (Roff et al., 2014).

In another non-comparative, multicenter trial, $\mathrm{CHC}$ patients, who were non-responders to Peg-IFN$\alpha /$ RBV were restarted on a standard regimen of PEG-IFN- $\alpha 2 a$ /RBV for 16 weeks, and for those did not reduce viral load by $2 \log (10)$ copies/mL, IFN $\gamma-1 b(100 \mu g$ three times per week) was added for the last 32 weeks of treatment. None of these patients reached un-detectability of HCV-RNA at week 28 and none had a decrease $>1 \log (10) \mathrm{IU} / \mathrm{mL}$, thus suggesting that this add-on strategy was not successful (Couzigou et al., 2013). In a randomized open-labeled multicenter trial involving 99 CHB patients, with proven fibrosis, injection of IFN- $\gamma(50 \mu \mathrm{g} /$ day for 3 months) was shown to significantly improves fibrosis scores most likely by antagonizing pro-fibrogenic transforming growth factor-beta (TGF- $\beta$ ) effects, but no effect on HBV replication was reported (Weng et al., 2005). Other long-term trials would be necessary to further investigate the positive (and safe) effect of IFN- $\gamma$ treatment in CHB patients, but as compared to IFN- $\lambda \mathrm{s}$, this type of IFN does not seem to be a priority.

\section{Non-IFN immune-modulators for the treatment of HBV infections or as adjuvant?}

\subsection{Cytokines}


Many pro-inflammatory cytokines, including tumor necrosis factor alpha (TNF- $\alpha$ ), interleukin 6 (IL-6), and interleukin 1 beta (IL-1 $\beta$ ) have been investigated for their direct or indirect anti-HBV effect. TNF- $\alpha$ is a 185 amino acids (aa) cytokine mainly secreted by macrophages and other myeloid cells, upon activation of the NF- $\kappa B$ pathway, in particular by TLR4 agonisation. TNF- $\alpha$ exerts its biological function on target cells by binding to either TNF- $\alpha$ R1 or TNF- $\alpha$ R2 of the TNF receptor superfamily. If TNF- $\alpha$ R1 is expressed in most nucleated cells, TNF- $\alpha$ R2 is mostly found at the surface of immune cells, and in particular on T-cells. Upon ligation as a trimer to its receptor, TNF- $\alpha$ can activate three signaling pathways, through TRADD mediation: NF-KB, MAP Kinase, and cell-death program via caspase 8 activation (Verstrepen et al., 2008) (Figure 2). In the late 90's, using the HBV transgenic model, the group of Franck Chisari showed in different published works that TNF- $\alpha$, as type-I and II IFNs, could be a mediator of the non-cytopathic inhibition of HBV replication in this model (Guidotti et al., 1999; Heise et al., 1999). However by crossing HBV-transgenic mice with mice deficient for IFN- $\alpha \mathrm{R}$, TNF- $\alpha \mathrm{R}$, or IFN- $\gamma$, it was found that TNF- $\alpha$ was not the main driver of the anti-HBV effect obtained by super-infecting mice with viruses (adenovirus or LCMV) inducing IFN and proinflammatory responses (McClary et al., 2000).

In vitro studies, performed in hepatocytes replicating HBV after stable transfection of pgRNA expression cassettes, reported that TNF- $\alpha$ could directly inhibit HBV replication in the absence of immune cells (Kawanishi et al., 1995). We, and others, have recently confirmed the direct antiviral effect of TNF- $\alpha$ in HBV-infected hepatocytes (Isorce et al., submitted; AVR-S-15-00187) (Watashi et al., 2013). The underlying mechanism could involve AID, a cytosine deaminase (Watashi et al., 2013), but also likely APOBEC3B, another DNA deaminase shown to induce degradation of cccDNA (Xia et al., EASL 2015), as well as mechanisms described in transgenic mice and involving destabilization of pgRNA capsids (Pasquetto et al., 2002) (Table 2).

The IL-6, a cytokine also secreted by myeloid cells, including macrophages, upon PRR stimulation, has been recently found to induce a direct anti-HBV effect in replicating hepatocytes (Hösel et al., 2009) (Isorce et al., submitted; AVR-S-15-00187). IL-6 acts through the binding to its receptor, IL-6R, composed of IL-6R $\alpha$ subunit (CD126) and gp130 (CD130), and activates STAT transcription factors, including STAT3 (Figure 2). In the context of HBV infection, it was found that IL-6 could mediate its anti-HBV action via inhibition of 
HNF4 $\alpha$, a hepato-specific transcription factor crucial for HBV transcription from cccDNA template (Hösel et

al., 2009). In a more general manner IL-6 seems to induce a hepatocyte dedifferentiation, which could contribute to HBV inhibition, as HBV replicates only in highly differentiated hepatocytes (Seeger et al., 2015). In this respect it was recently found that another mechanism to explain the anti-HBV effect of IL-6 could be related to the down-regulation of the HBV entry receptor expression (Bouezzedine et al., 2015), namely NTCP (sodium ( $\mathrm{Na}^{+}$) taurocholate co-transporting polypeptide) (Table 2).

The IL-1 $\beta$ is a member of the large IL-1 family of cytokines (Verstrepen et al., 2008). This highly proinflammatory cytokine is produced and secreted mainly by activated macrophages/monocytes-derived macrophages in reaction to a pathogen intrusion, in the context of chronic infections, or in association with auto-inflammatory syndromes. In most cases, the production and secretion of IL-1 $\beta$ is a two-step regulated process. IL-1 $\beta$ is initially produced intracellularly as pro-IL-1 $\beta$ upon the activation of the NF-KB pathways via engagement of a PRR (e.g. TLR4 or TLR2), but needs the concomitant activation of one inflammasome leading to the activation of caspase 1 , which in turn cleaves pro-IL-1 $\beta$ to generate secreted IL-1 $\beta$. Several inflammasomes have been characterized, involving NLRP1, NLRP3, NLRC4, or AIM2 (and many others) as molecules organizing, together with ASC, the proteolytic platform (Ulland et al., 2015). The same regulation applies for the production of IL-18, another chemokine produced concomitantly to IL-1 $\beta$. IL-1 $\beta$ mediates its action on target cells by binding to the dimeric IL-1-receptor composed of IL-1RI and IL-1RAcP, which in turn, via the Myd88 adaptor, leads to the activation of signaling pathway involving NF- $\mathrm{KB}$ as transcription factor (Figure 2). As IL-1 $\beta$ is mainly associated with detrimental long-term inflammation, the main therapeutic issue around this cytokine consist of the inactivation of its action. Many strategies, involving a recombinant soluble receptor antagonist (anakinra; for the treatment of rheumatoid arthritis for instance) or the more recent anti-IL-1b MAbs (i.e. canakinumab or gevokinumab), have been developed to block IL-1 $\beta$ action (Ulland et al., 2015).

Until recently IL-1 $\beta$ was not identified as a cytokine bearing direct antiviral activity. But a work performed by Watashi and colleagues has revealed that, amongst 36 cytokines/chemokines, pretreatment (prior to infection with HBV) of HepaRG cells with IL-1 (or TNF- $\alpha$ ) could lead to a potent anti-HBV phenotype. In this study they identified AID, a cytosine deaminase, as a potential effector of the antiviral 
effect. We have confirmed the antiviral activity of IL-1 $1 \beta$ in a different context. Indeed we treated either HBVinfected HepaRG or PHH with cytokines/chemokines when the infection was already established, and found that IL-1 $\beta$ was the most potent molecule, leading after only one dosing and $72 \mathrm{~h}$ of exposure to the cytokine to potent effect on intracellular HBV DNA ("inhibitory concentration $50 \%$ " at $25 \mathrm{pg} / \mathrm{mL}$ in this model) (Isorce et al., submitted; AVR-S-15-00187). The MOA of IL-1 $\beta$ is rather complex, as it involves an initial silencing of cccDNA transcription via an "inhibitory NF-KB binding" to cccDNA (phenotype observed after a single dosing of IL-1 $1 \beta$, independently of secondary cytokines (IL-6) produced upon IL-1 $\beta$ exposure), followed by a dedifferentiation (HNF4 $\alpha$, albumin and ApoB decreased expression and secretion) of hepatocytes, which has as discussed previously also an effect on transcription (Hösel et al., 2009), and likely the expression of effectors responsible for cccDNA destabilization (phenotype obtained after several treatments and 3 days single treatment with IL-1 $\beta$ ), including the deaminase APOBEC3B (Isorce et al., unpublished results) (Table

2). There are also preliminary genetic evidences of the importance of IL-1 $\beta$ for the regulation of the replication of HBV in vivo (Tunçbilek, 2014); nevertheless GWAS studies remains to be conducted on well designed cohort of $\mathrm{CHB}$ patients to further reinforce these evidences.

The systemic use of recombinant IL-1 $\beta$ in the context of $\mathrm{CHB}$ treatment is not envisageable due to the expected toxicity of such an approach. One would have maybe to determine whether this cytokine could be delivered to the liver compartment using nanoparticles or other ad hoc approaches. Alternatively, an acceptable strategy would be to induce endogenous production of IL-1 $\beta$ within liver microenvironment by targeted strategies (Figure 3). In this respect, we need to further understand the interplay between HBV and Kupffer cells (i.e. resident macrophages) as well as with other resident or recruited myeloid cells, to find a way to unlock viro-induced blockades (see section 5).

\subsection{Chemokines as adjuvant?}

Chemokines could also be considered to boost immune responses against HBV. In the transgenic model of HBV, it was shown that IL-2, IL-12 and IL-18 could induce the inhibition of HBV replication (Cavanaugh et al., 1997; Guidotti et al., 1994; Kimura et al., 2002). These three chemokines, which are produced by DCs, and macrophages, are important to favor production of IFN- $\gamma$ by NK/NKT and T cells. They can be produced by stimulation with PRR agonist, and TLR8 agonist has been shown to be very potent in this respect in the liver 
(Jo et al., 2014). Recombinant forms of these cytokines have not yet been widely used, but several trials performed in animal model or in human, and aiming at investigating DNA vaccination as therapeutic approach have used co-injection of vectors encoding these chemokines, and shown that they indeed improved immune responses (Brass et al., 2015; Chow et al., 1998; Saade et al., 2013; Yang et al., 2012). However therapeutic DNA vaccination strategies are yet being developed. In the mean time knowledge on the role of chemokines, including those which had recently "come into light" with respect to liver immunology (e.g. IL-17, IL-23, IL-33, IL-35...), is also growing, and we may expect great improvement of such strategies in the near future (Tables 1 and 2 ).

\subsection{Other strategies}

Rather than using an IFN/cytokine/chemokine itself, monoclonal antibodies capable to specifically bind and agonize a given receptor of interest could be used. This approach presents the advantage of using the tremendous knowledge that has been recently generated regarding GMP-production of humanized monoclonal antibodies (MAbs) for many indications and clinical uses. This approach was nicely exemplified recently in the HBV field by using an agonistic MAb directed against the lymphotoxin-beta receptor (LT- $\beta$ R).

CBE11 and BS1 have been used to stimulate the LT- $\beta$ R in HBV-infected cells and shown to be able to induce an extremely potent antiviral effect in HBV-infected hepatocytes in the absence of any immune cells. Amongst stimulated genes was the gene encoding APOBEC3B, a nuclear member of the APOBEC family involved in DNA deamination. It was then convincingly demonstrated that APOBEC3B could induce the degradation of cccDNA in a non-cytopathic manner in these infected cells (Lucifora et al., 2014) (Figure 4). As the non controlled activation of the LT- $\beta /$ LT- $\beta$ R axis in the liver is involved in hepatocellular carcinogenesis (Haybaeck et al., 2009) and APOBEC3B has been genetically associated with breast cancer (Nik-Zainal et al., 2014), one can wonder whether these antibodies could be use in the context of chronic viral infections, and careful safety/toxicity studies are warranted.

\section{Strategies to restore depleted "immune-modulator-mediated" functions}

\subsection{Strategies to restore endogenous production of cytokines/IFNs}




\subsubsection{PRR agonists}

The use of recombinant IFNs/cytokines/chemokines for therapeutic purposes can have limitations. Indeed systemic injection of these molecules is not always possible due to possible "stormy inflammation" leading to toxicity or risks of induction of autoimmunity events. The restoration of the endogenous production IFNs/cytokines/chemokines in a targeted manner could represent an interesting approach. Regarding IFNs, this strategy could enable the production of a wider variety of IFNs (i.e. many subtype can be produced by pDCs in contrast to the unique subtype exogenously injected) at the site of replication. If hepatocytes can produce type-I and III IFNs via the stimulation of PRR (Luangsay et al., 2015), there are two main types of cells specialized in the productions of IFN- $\alpha$ and IFN- $\lambda$ : the pDC and the mDC-BDCA3(+)/CLEC9A(+) (Dalod et al., 2014; van der Aa et al., 2015). The first cell type can be stimulated by either TLR7 or TLR9 ligands, whether the second is the main cell type expressing TLR3 in the liver, and can be activated by cognate ligands. When activated these cells produce IFNs as well as other cytokines/chemokines that could activate in turn other innate immune cells and in fine adaptive cells. Hence, agonist-induced activation of PRR could represent a novel approach for the treatment of chronic hepatotropic viral infections; this of course is theoretically possible if the virus is not capable to inhibit PRR and their signaling pathways.

In the case of HBV, studies aiming at understanding the interplay between HBV and PRR pathways are yet necessary to clearly define this landscape. However, interestingly, in HBV-infected chimpanzees, GS9620, an orally administered agonist of TLR-7, was found to induce a strong anti-HBV effect with a 2-log10 reduction in viremia in the majority of animals tested (Lanford et al., 2013). Surprisingly, short-term administration of GS-9620 led to off-drug, long-term suppression of serum and liver HBV DNA, thus suggesting that cccDNA could be targeted. Moreover, it was found that serum levels of $\mathrm{HBs} A g$ and $\mathrm{HBeAg}$, as well as the numbers of HBV-antigen-positive hepatocytes, were reduced. As expected, GS-9620 administration induced the production of IFN- $\alpha$ (most likely by pDCs) and other cytokines/chemokines, upregulated ISGs expression in the liver, and activated NK cells and other lymphocyte subsets. Importantly, similar effects were also observed in chronically infected woodchucks treated by GS-9620, with confirmation of the long lasting off-drug effect (Menne et al., 2015). Following these studies, a phase-I clinical evaluation, aiming at evaluating the safety of this drug in human was initiated, and patients are now 
being enrolled in a phase II trial combining tenofovir and GS-9620 in comparison to tenofovir monotherapy (Gane et al., 2015). More data on the potential use of PRR agonists for the treatment of CHB are given in another review of this symposium (see Chang \& Guo; AVR-D-15-00165).

\subsubsection{Other investigational strategies}

Beside IFNs, we have seen that other cytokines, including in particular IL-1 $\beta$, could bear strong anti-HBV activity. The production of this cytokine by liver macrophages (Kupffer cells) is blocked by HBV via a molecular mechanism yet to be fully uncovered, but likely involving both the inhibition of IFN response (Gruffaz et al., 2013) and AIM-2 inflammasome (Zannetti et al., 2013) by viral proteins. The understanding of the molecular inhibitory mechanisms at works could help us defining strategies to unlock them in a therapeutic perspective (Figure 3 and 4). Macrophages seem to be particularly targeted by HBV as for its immune evasion strategy. Hence, it was convincingly shown that TLR2, a master PRR in this cell type, is down-regulated in HBe-positive patients in monocytes/macrophages both in the blood and liver compartment (Visvanathan et al., 2007). Moreover in the woodchuck model of WHB infection, long-term therapy with NUC was associated with restoration of TLR2 expression (Zhang et al., 2012). Therefore a concept combination therapy with NUC and TLR2 agonist could be envisaged to restore innate immune functions in the liver microenvironment (Durantel and Zoulim, 2012), which could also implicate the local re-secretion of endogenous IL-1 $\beta$ by macrophages.

\subsection{Blockade or depletion of immune-inhibitory signals or cells}

In chronic HBV infection, the lack of T-cell-mediated specific responses against the virus is, at least partially, due to an exhaustion phenotype. This phenotype is characterized by the scarcity or absence of HBV-specific T cells, associated with poor effector cytotoxicity activity, impaired cytokine production, and sustained expression of co-inhibitory receptors, including programmed cell death (PD-1), cytotoxic T lymphocyteassociated antigen-4 (CTLA-4 or CD152), lymphocyte activation gene 3 (Lag-3), T-cell immunoglobulin domain and mucin domain 3 (TIM-3), and CD244 (2B4). This exhausted phenotype is maintained by the presence in the microenvironment of immunosuppressive cytokines/chemokines, including IL-10 and TGF- $\beta$, produced by tolerogenic-prone innate cells and T-reg cells that are enriched in the liver of CHB patients 
(Rehermann and Bertoletti, 2015; Ye et al., 2015).

Recent studies in the field of cancer therapy have highlighted the clinical relevance of the blockade of these co-inhibitory receptors via antibodies. Hence in advanced melanoma, the use in combination of nivolumab (anti-PD-1) and ipilimimab (anti-CTLA-4) has been shown to be associated with a significant increase in survival (Wolchok et al., 2013). As chronic HBV infection and tumor immunology share similar characteristics in terms of immune subversion, blockade co-inhibitory receptors may be an attractive concept for HBV therapy. In a mouse model of HBV persistence, it was recently shown that anti-PD-1 could reverse immune dysfunctions and help clearing HBV to some extend ( $60 \%$ negativity for HBsAg compared to $20 \%$ in control animals) (Tzeng et al., 2012). Recent studies performed in chronically infected woodchucks have tested the anti-WHV (woodchuck hepatitis virus) effect of a combination of ETV, anti-PD-L1 MAb, and WHV DNA vaccine. PD-L1 blockade was shown to synergize with ETV and therapeutic vaccination to control viral replication and restore WHV-specific T cell responses (Liu et al., 2014). Moreover, in ex vivo experiments (on $\mathrm{CD}^{+} \mathrm{T}$ cells isolated from $98 \mathrm{CHB}$ patients) aiming at comparing the efficacy of inhibitory receptor blockade strategies targeting PD-1, 2B4, Tim-3, CTLA-4, and BTLA (B and T lymphocytes attenuator), it was shown that the anti-PD-1 led to the strongest restoration of function, thus suggesting a dominance of PD-1/PD-L1 blockade in the context of CHB. Further evaluations are needed, using one or several antireceptors, maybe also combined with the blockade of immunosuppressive cytokines/chemokines by antibodies, to take forward these strategies into clinical trials.

\section{Conclusions}

Acute HBV infections are cleared in $90 \%$ of cases in immune-competent adults thanks to a strong and adapted immune response. A long-term, and off treatment, control of chronic infections beyond NUCmediated viro-suppression will require a rupture of tolerance and restoration of specific immune responses against the virus. In this respect, immune-modulators, other than IFN- $\alpha$, may represent an interesting addition to the therapeutic arsenal. In particular peg-IFN- $\lambda$, which has shown equivalent anti-HCV properties, but with a better toxicity profile than IFN- $\alpha$, should be tested in $\mathrm{CHB}$ patients. In parallel the efforts to develop molecules capable to induce the endogenous production of IFNs, or other 
cytokines/chemokines, should be pursued. In this line, the results of human trials with the TLR7 agonist from Gilead Sciences (GS-9620) are eagerly awaited, as this strategy could better recapitulate the mounting of a more physiologic immune response, thanks to the endogenous production of different subtypes of IFNs (and other cytokines) collectively bearing wider antiviral properties. Basic research to better understand the interplay between HBV and the immune system should remain more than ever in the agenda of HBV researchers to further fuel these therapeutic concepts. 


\section{References}

Ahmed, C.M.I., Johnson, H.M., 2006. IFN- $\gamma$ and Its Receptor Subunit IFNGR1 Are Recruited to the IFN- $\gamma$-Activated Sequence Element at the Promoter Site of IFN- $\gamma$-Activated Genes: Evidence of Transactivational Activity in IFNGR1. The Journal of Immunology 177, 315-321.

Allweiss, L., Volz, T., Lutgehetmann, M., Giersch, K., Bornscheuer, T., Lohse, A.W., Petersen, J., Ma, H., Klumpp, K., Fletcher, S.P., Dandri, M., 2014. Immune cell responses are not required to induce substantial hepatitis $B$ virus antigen decline during pegylated interferon-alpha administration. J Hepatol 60, 500-507.

Bacon, B.R., Shiffman, M.L., Mendes, F., Ghalib, R., Hassanein, T., Morelli, G., Joshi, S., Rothstein, K., Kwo, P., Gitlin, N., 2009. Retreating chronic hepatitis $C$ with daily interferon alfacon-1/ribavirin after nonresponse to pegylated interferon/ribavirin: DIRECT results. Hepatology 49, 1838-1846.

Begitt, A., Droescher, M., Meyer, T., Schmid, C.D., Baker, M., Antunes, F., Knobeloch, K.P., Owen, M.R., Naumann, R., Decker, T., Vinkemeier, U., 2014. STAT1-cooperative DNA binding distinguishes type 1 from type 2 interferon signaling. Nature immunology 15, 168-176.

Belloni, L., Allweiss, L., Guerrieri, F., Pediconi, N., Volz, T., Pollicino, T., Petersen, J., Raimondo, G., Dandri, M., Levrero, M., 2012. IFN- $\alpha$ inhibits HBV transcription and replication in cell culture and in humanized mice by targeting the epigenetic regulation of the nuclear cccDNA minichromosome. J. Clin. Invest. 122, 529-537.

Bouezzedine, F., Fardel, O., Gripon, P., 2015. Interleukin 6 inhibits HBV entry through NTCP down regulation. Virology 481, 34-42.

Brass, A., Frelin, L., Milich, D.R., Sallberg, M., Ahlen, G., 2015. Functional aspects of intrahepatic hepatitis $B$ virus-specific T cells induced by therapeutic DNA vaccination. Molecular therapy : the journal of the American Society of Gene Therapy 23, 578-590.

Caselmann, W.H., Meyer, M., Scholz, S., Hofschneider, P.H., Koshy, R., 1992. Type I interferons inhibit hepatitis $B$ virus replication and induce hepatocellular gene expression in cultured liver cells. The Journal of infectious diseases 166, 966-971.

Cavanaugh, V.J., Guidotti, L.G., Chisari, F.V., 1997. Interleukin-12 inhibits hepatitis B virus replication in transgenic mice. J. Virol. 71, 3236-3243.

Chen, J.Y., Feeney, E.R., Chung, R.T., 2014. HCV and HIV co-infection: mechanisms and management. Nat Rev Gastroenterol Hepatol 11, 362-371.

Chow, Y.-H., Chiang, B.-L., Lee, Y.-L., Chi, W.-K., Lin, W.-C., Chen, Y.-T., Tao, M.-H., 1998. Development of Th1 and Th2 Populations and the Nature of Immune Responses to Hepatitis B Virus DNA Vaccines Can Be Modulated by Codelivery of Various Cytokine Genes. The Journal of Immunology 160, 1320-1329.

Ciancio, A., Rizzetto, M., 2014. Chronic hepatitis D at a standstill: where do we go from here? Nat Rev Gastroenterol Hepatol 11, 68-71.

Colvin, R.A., Tanwandee, T., Piratvisuth, T., Thongsawat, S., Hui, A.J., Zhang, H., Ren, H., Chen, P.J., Chuang, W.L., Sobhonslidsuk, A., Li, R., Qi, Y., Praestgaard, J., Han, Y., Xu, J., Stein, D.S., Group, A.A.S., 2015. Randomized, controlled pharmacokinetic and pharmacodynamic evaluation of albinterferon in patients with chronic hepatitis B infection. J Gastroenterol Hepatol 30, 184191.

Couzigou, P., Pérusat, S., Bourlière, M., Trimoulet, P., Poynard, T., Leroy, V., Marcellin, P., Foucher, J., Bronowicki, J.-P., Chêne, G., Group, A.H.G.T., 2013. Interferon-gamma with peginterferon 
alpha-2a and ribavirin in nonresponder patients with chronic hepatitis C (ANRS HC16 GAMMATRI). J. Gastroenterol. Hepatol. 28, 329-334.

Crouse, J., Kalinke, U., Oxenius, A., 2015. Regulation of antiviral T cell responses by type I interferons. Nat Rev Immunol 15, 231-242.

Dalod, M., Chelbi, R., Malissen, B., Lawrence, T., 2014. Dendritic cell maturation: functional specialization through signaling specificity and transcriptional programming. The EMBO Journal 33, 1104-1116.

Dumoutier, L., Tounsi, A., Michiels, T., Sommereyns, C., Kotenko, S.V., Renauld, J.C., 2004. Role of the interleukin (IL)-28 receptor tyrosine residues for antiviral and antiproliferative activity of IL29/interferon-lambda 1: similarities with type I interferon signaling. J Biol Chem 279, 3226932274.

Durantel, D., Zoulim, F., 2012. Interplay between hepatitis B virus and TLR2-mediated innate immune responses: can restoration of TLR2 functions be a new therapeutic option? J Hepatol 57, 486-489.

EASL, 2012. EASL Clinical Practice Guidelines: Management of chronic hepatitis B virus infection. Journal of hepatology.

Egli, A., Santer, D.M., O'Shea, D., Tyrrell, D.L., Houghton, M., 2014. The impact of the interferonlambda family on the innate and adaptive immune response to viral infections. Emerging microbes \& infections 3, e51.

Escuret, V., Martin, A., Durantel, D., Parent, R., Hantz, O., Trepo, C., Menguy, T., Bottius, E., Dardy, J., Maral, J., Escary, J.L., Zoulim, F., 2006. Novel alpha interferon (IFN-alpha) variant with improved inhibitory activity against hepatitis $C$ virus genotype 1 replication compared to IFNalpha2b therapy in a subgenomic replicon system. Antimicrob Agents Chemother 50, 39843991.

Feld, J.J., 2014. The beginning of the end: What is the future of interferon therapy for chronic hepatitis C? Antiviral Res. 105, 32-38.

Foster, G.R., 2010. Pegylated interferons for the treatment of chronic hepatitis C: pharmacological and clinical differences between peginterferon-alpha-2a and peginterferon-alpha-2b. Drugs 70 , 147-165.

Gane, E.J., Lim, Y.-S., Gordon, S.C., Visvanathan, K., Sicard, E., Fedorak, R.N., Roberts, S., Massetto, B., Ye, Z., Pflanz, S., Garrison, K.L., Gaggar, A., Mani Subramanian, G., McHutchison, J.G., Kottilil, S., Freilich, B., Coffin, C.S., Cheng, W., Kim, Y.J., 2015. The Oral Toll-Like Receptor-7 Agonist GS9620 in Patients with Chronic Hepatitis B Virus Infection. J. Hepatol.

Gish, R.G., Given, B.D., Lai, C.-L., Locarnini, S.A., Lau, J.Y.N., Lewis, D.L., Schluep, T., 2015. Chronic hepatitis B: Virology, natural history, current management and a glimpe at future opportunities. Antiviral Res., In press.

Gordien, E., Rosmorduc, O., Peltekian, C., Garreau, F., Brechot, C., Kremsdorf, D., 2001. Inhibition of hepatitis $B$ virus replication by the interferon-inducible MxA protein. J Virol 75, 2684-2691.

Gruffaz, M., Testoni, B., Luangsay, S., Ait-Goughoulte, M., Petit, M.A., Ma, H., Klumpp, K., Javanbakht, H., Durantel, D., Zoulim, F., 2013. HEPATITIS B CORE (HBC) PROTEIN IS A KEY AND VERY EARLY NEGATIVE REGULATOR OF THE INTERFERON RESPONSE. J. Hepatol. 58, S155-S156.

Guidotti, L.G., Borrow, P., Hobbs, M.V., Matzke, B., Gresser, I., Oldstone, M.B., Chisari, F.V., 1996a. Viral cross talk: intracellular inactivation of the hepatitis $B$ virus during an unrelated viral infection of the liver. PNAS 93, 4589-4594.

Guidotti, L.G., Guilhot, S., Chisari, F.V., 1994. Interleukin-2 and alpha/beta interferon downregulate hepatitis $B$ virus gene expression in vivo by tumor necrosis factor-dependent and independent pathways. J Virol 68, 1265-1270.

Guidotti, L.G., Ishikawa, T., Hobbs, M.V., Matzke, B., Schreiber, R., Chisari, F.V., 1996b. Intracellular inactivation of the hepatitis B virus by cytotoxic T lymphocytes. Immunity 4, 25-36. 
Guidotti, L.G., Morris, A., Mendez, H., Koch, R., Silverman, R.H., Williams, B.R., Chisari, F.V., 2002. Interferon-regulated pathways that control hepatitis $B$ virus replication in transgenic mice. J Virol 76, 2617-2621.

Guidotti, L.G., Rochford, R., Chung, J., Shapiro, M., Purcell, R., Chisari, F.V., 1999. Viral Clearance Without Destruction of Infected Cells During Acute HBV Infection. Science 284, 825-829.

Haybaeck, J., Zeller, N., Wolf, M.J., Weber, A., Wagner, U., Kurrer, M.O., Bremer, J., lezzi, G., Graf, R., Clavien, P.-A., Thimme, R., Blum, H., Nedospasov, S.A., Zatloukal, K., Ramzan, M., Ciesek, S., Pietschmann, T., Marche, P.N., Karin, M., Kopf, M., Browning, J.L., Aguzzi, A., Heikenwalder, M., 2009. A Lymphotoxin-Driven Pathway to Hepatocellular Carcinoma. Cancer Cell 16, 295-308.

Heidrich, B., Yurdaydin, C., Kabacam, G., Ratsch, B.A., Zachou, K., Bremer, B., Dalekos, G.N., Erhardt, A., Tabak, F., Yalcin, K., Gurel, S., Zeuzem, S., Cornberg, M., Bock, C.T., Manns, M.P., Wedemeyer, H., Group, H.-S., 2014. Late HDV RNA relapse after peginterferon alpha-based therapy of chronic hepatitis delta. Hepatology 60, 87-97.

Heise, T., Guidotti, L.G., Cavanaugh, V.J., Chisari, F.V., 1999. Hepatitis B virus RNA-binding proteins associated with cytokine-induced clearance of viral RNA from the liver of transgenic mice. J. Virol. 73, 474-481.

Hösel, M., Quasdorff, M., Wiegmann, K., Webb, D., Zedler, U., Broxtermann, M., Tedjokusumo, R., Esser, K., Arzberger, S., Kirschning, C.J., Langenkamp, A., Falk, C., Büning, H., Rose-John, S., Protzer, U., 2009. Not interferon, but interleukin-6 controls early gene expression in hepatitis $B$ virus infection. Hepatology 50, 1773-1782.

Isogawa, M., Robek, M.D., Furuichi, Y., Chisari, F.V., 2005. Toll-like receptor signaling inhibits hepatitis $B$ virus replication in vivo. J Virol 79, 7269-7272.

Issacs, A., Lindenmann, J., 1957a. Virus interference I: the interferon. Proc R Soc Lond. 147, 258267.

Issacs, A., Lindenmann, J., 1957b. Virus interference, II: some properties of interferon. . Proc R Soc Lond. 147, 268-273.

Iwasaki, A., Medzhitov, R., 2013. Innate responses to viral infections, in: Knipe, D., Howley, P. (Eds.), Fields Virology. Lippincott Williams \& Wilkins, Philadelphia, pp. 189-213.

Janssen, H.L.A., van Zonneveld, M., Senturk, H., Zeuzem, S., Akarca, U.S., Cakaloglu, Y., Simon, C., So, T.M.K., Gerken, G., de Man, R.A., Niesters, H.G.M., Zondervan, P., Hansen, B., Schalm, S.W., 2005. Pegylated interferon alfa-2b alone or in combination with lamivudine for HBeAg-positive chronic hepatitis B: a randomised trial. The Lancet 365, 123-129.

Jo, J., Tan, A.T., Ussher, J.E., Sandalova, E., Tang, X.Z., Tan-Garcia, A., To, N., Hong, M., Chia, A., Gill, U.S., Kennedy, P.T., Tan, K.C., Lee, K.H., De Libero, G., Gehring, A.J., Willberg, C.B., Klenerman, P., Bertoletti, A., 2014. Toll-like receptor 8 agonist and bacteria trigger potent activation of innate immune cells in human liver. PLoS Pathog 10, e1004210.

Kang, K.W., Wagley, Y., Kim, H.W., Pokharel, Y.R., Chung, Y.Y., Chang, I.Y., Kim, J.J., Moon, J.S., Kim, Y.K., Nah, S.Y., Kang, H.S., Oh, J.W., 2007. Novel role of IL-6/SIL-6R signaling in the expression of inducible nitric oxide synthase (iNOS) in murine B16, metastatic melanoma clone F10.9, cells. Free Radic Biol Med 42, 215-227.

Kao, J.H., 2014. HBeAg-positive chronic hepatitis B: why do I treat my patients with pegylated interferon? Liver international : official journal of the International Association for the Study of the Liver 34 Suppl 1, 112-119.

Kawanishi, Y., Hayashi, N., Katayama, K., Ueda, K., Takehara, T., Miyoshi, E., Mita, E., Kasahara, A., Fusamoto, H., Kamada, T., 1995. Tumor necrosis factor-alpha and interferon-gamma inhibit synergistically viral replication in hepatitis B virus-replicating cells. J. Med. Virol. 47, 272-277.

Khan, U.T., Tanasescu, R., Constantinescu, C.S., 2015. PEGylated IFNbeta-1a in the treatment of multiple sclerosis. Expert opinion on biological therapy 15, 1077-1084. 
Kimura, K., Kakimi, K., Wieland, S., Guidotti, L.G., Chisari, F.V., 2002. Interleukin-18 inhibits hepatitis B virus replication in the livers of transgenic mice. J. Virol. 76, 10702-10707.

Koh, S., Bertoletti, A., 2015. Circumventing failed antiviral immunity in chronic hepatitis B virus infection: triggering virus-specific or innate-like T cell response? Med. Microbiol. Immunol. 204, 87-94.

Lanford, R.E., Guerra, B., Chavez, D., Giavedoni, L., Hodara, V.L., Brasky, K.M., Fosdick, A., Frey, C.R., Zheng, J., Wolfgang, G., Halcomb, R.L., Tumas, D.B., 2013. GS-9620, an oral agonist of Toll-like receptor-7, induces prolonged suppression of hepatitis $B$ virus in chronically infected chimpanzees. Gastroenterology 144, 1508-1517, 1517.e1501-1510.

Lau, G.K.K., Piratvisuth, T., Luo, K.X., Marcellin, P., Thongsawat, S., Cooksley, G., Gane, E., Fried, M.W., Chow, W.C., Paik, S.W., Chang, W.Y., Berg, T., Flisiak, R., McCloud, P., Pluck, N., 2005. Peginterferon Alfa-2a, Lamivudine, and the Combination for HBeAg-Positive Chronic Hepatitis B. New England Journal of Medicine 352, 2682-2695.

Leonard, W., 2013. Type I cytokines and interferons, an their receptors, in: Paul, W. (Ed.), Fundamental Immunology. Lippincott Williams \& Wilkins, Philadelphia, pp. 601-638.

Lin, F.C., Young, H.A., 2014. Interferons: Success in anti-viral immunotherapy. Cytokine \& growth factor reviews 25, 369-376.

Liu, J., Zhang, E., Ma, Z., Wu, W., Kosinska, A., Zhang, X., Moller, I., Seiz, P., Glebe, D., Wang, B., Yang, D., Lu, M., Roggendorf, M., 2014. Enhancing virus-specific immunity in vivo by combining therapeutic vaccination and PD-L1 blockade in chronic hepadnaviral infection. PLoS Pathog 10, e1003856.

Luangsay, S., Ait-Goughoulte, M., Michelet, M., Floriot, O., Bonnin, M., Gruffaz, M., Rivoire, M., Fletcher, S., Javanbakht, H., Lucifora, J., Zoulim, F., Durantel, D., 2015. Expression and Functionality of Toll- and RIG-like receptors in HepaRG Cells. J. Hepatol., In press.

Lucifora, J., Xia, Y., Reisinger, F., Zhang, K., Stadler, D., Cheng, X., Sprinzl, M.F., Koppensteiner, H., Makowska, Z., Volz, T., Remouchamps, C., Chou, W.-M., Thasler, W.E., Hüser, N., Durantel, D., Liang, T.J., Münk, C., Heim, M.H., Browning, J.L., Dejardin, E., Dandri, M., Schindler, M., Heikenwalder, M., Protzer, U., 2014. Specific and nonhepatotoxic degradation of nuclear hepatitis B virus cccDNA. Science 343, 1221-1228.

Makowska, Z., Duong, F.H., Trincucci, G., Tough, D.F., Heim, M.H., 2011. Interferon-beta and interferon-lambda signaling is not affected by interferon-induced refractoriness to interferonalpha in vivo. Hepatology 53, 1154-1163.

Mao, R., Nie, H., Cai, D., Zhang, J., Liu, H., Yan, R., Cuconati, A., Block, T.M., Guo, J.-T., Guo, H., 2013. Inhibition of Hepatitis B Virus Replication by the Host Zinc Finger Antiviral Protein. PLoS Pathog 9, e1003494.

Marcellin, P., Heathcote, E.J., Buti, M., Gane, E., de Man, R.A., Krastev, Z., Germanidis, G., Lee, S.S., Flisiak, R., Kaita, K., Manns, M., Kotzev, I., Tchernev, K., Buggisch, P., Weilert, F., Kurdas, O.O., Shiffman, M.L., Trinh, H., Washington, M.K., Sorbel, J., Anderson, J., Snow-Lampart, A., Mondou, E., Quinn, J., Rousseau, F., 2008. Tenofovir disoproxil fumarate versus adefovir dipivoxil for chronic hepatitis B. N Engl J Med 359, 2442-2455.

Marcellin, P., Lau, G.K.K., Bonino, F., Farci, P., Hadziyannis, S., Jin, R., Lu, Z.-M., Piratvisuth, T., Germanidis, G., Yurdaydin, C., Diago, M., Gurel, S., Lai, M.-Y., Button, P., Pluck, N., 2004. Peginterferon Alfa-2a Alone, Lamivudine Alone, and the Two in Combination in Patients with HBeAg-Negative Chronic Hepatitis B. New England Journal of Medicine 351, 1206-1217.

McClary, H., Koch, R., Chisari, F.V., Guidotti, L.G., 2000. Relative sensitivity of hepatitis B virus and other hepatotropic viruses to the antiviral effects of cytokines. J. Virol. 74, 2255-2264.

McMahon, B.J., 2014. Chronic Hepatitis B Virus Infection. Medical Clinics of North America 98, 3954. 
Menne, S., Tumas, D.B., Liu, K.H., Thampi, L., AlDeghaither, D., Baldwin, B.H., Bellezza, C.A., Cote, P.J., Zheng, J., Halcomb, R., Fosdick, A., Fletcher, S.P., Daffis, S., Li, L., Yue, P., Wolfgang, G.H.I., Tennant, B.C., 2015. Sustained efficacy and seroconversion with the Toll-like receptor 7 agonist GS-9620 in the Woodchuck model of chronic hepatitis B. J. Hepatol. 62, 1237-1245.

Micco, L., Peppa, D., Loggi, E., Schurich, A., Jefferson, L., Cursaro, C., Panno, A.M., Bernardi, M., Brander, C., Bihl, F., Andreone, P., Maini, M.K., 2013. Differential boosting of innate and adaptive antiviral responses during pegylated-interferon-alpha therapy of chronic hepatitis B. Journal of hepatology 58, 225-233.

Muir, A.J., Arora, S., Everson, G., Flisiak, R., George, J., Ghalib, R., Gordon, S.C., Gray, T., Greenbloom, S., Hassanein, T., Hillson, J., Horga, M.A., Jacobson, I.M., Jeffers, L., Kowdley, K.V., Lawitz, E., Lueth, S., Rodriguez-Torres, M., Rustgi, V., Shemanski, L., Shiffman, M.L., Srinivasan, S., Vargas, H.E., Vierling, J.M., Xu, D., Lopez-Talavera, J.C., Zeuzem, S., 2014. A randomized phase $2 \mathrm{~b}$ study of peginterferon lambda- $1 \mathrm{a}$ for the treatment of chronic HCV infection. J. Hepatol. 61, 1238-1246.

Murphy, P., 2013. Chemokines, in: Paul, W. (Ed.), Fundamental Immunology. Lippincott Williams \& Wilkins, Philadelphia, pp. 681-707.

Nakagawa, S.-i., Hirata, Y., Kameyama, T., Tokunaga, Y., Nishito, Y., Hirabayashi, K., Yano, J., Ochiya, T., Tateno, C., Tanaka, Y., Mizokami, M., Tsukiyama-Kohara, K., Inoue, K., Yoshiba, M., Takaoka, A., Kohara, M., 2013. Targeted induction of interferon- $\lambda$ in humanized chimeric mouse liver abrogates hepatotropic virus infection. PLoS ONE 8.

Nelson, D.R., Benhamou, Y., Chuang, W.L., Lawitz, E.J., Rodriguez-Torres, M., Flisiak, R., Rasenack, J.W., Kryczka, W., Lee, C.M., Bain, V.G., Pianko, S., Patel, K., Cronin, P.W., Pulkstenis, E., Subramanian, G.M., McHutchison, J.G., Team, A.-S., 2010. Albinterferon Alfa-2b was not inferior to pegylated interferon-alpha in a randomized trial of patients with chronic hepatitis $C$ virus genotype 2 or 3. Gastroenterology 139, 1267-1276.

Nguyen, D.H., Gummuluru, S., Hu, J., 2007. Deamination-independent inhibition of hepatitis B virus reverse transcription by APOBEC3G. J Virol 81, 4465-4472.

Nik-Zainal, S., Wedge, D.C., Alexandrov, L.B., Petljak, M., Butler, A.P., Bolli, N., Davies, H.R., Knappskog, S., Martin, S., Papaemmanuil, E., Ramakrishna, M., Shlien, A., Simonic, I., Xue, Y., Tyler-Smith, C., Campbell, P.J., Stratton, M.R., 2014. Association of a germline copy number polymorphism of APOBEC $3 A$ and APOBEC3B with burden of putative APOBEC-dependent mutations in breast cancer. Nat Genet 46, 487-491.

Ozes, O.N., Reiter, Z., Klein, S., Blatt, L.M., Taylor, M.W., 1992. A comparison of interferon-Con1 with natural recombinant interferons-alpha: antiviral, antiproliferative, and natural killerinducing activities. Journal of interferon research 12, 55-59.

Pagliaccetti, N.E., Chu, E.N., Bolen, C.R., Kleinstein, S.H., Robek, M.D., 2010. Lambda and alpha interferons inhibit hepatitis $B$ virus replication through a common molecular mechanism but with different in vivo activities. Virology 401, 197-206.

Pasquetto, V., Guidotti, L.G., Kakimi, K., Tsuji, M., Chisari, F.V., 2000. Host-virus interactions during malaria infection in hepatitis B virus transgenic mice. The Journal of experimental medicine 192, 529-536.

Pasquetto, V., Wieland, S.F., Uprichard, S.L., Tripodi, M., Chisari, F.V., 2002. Cytokine-sensitive replication of hepatitis B virus in immortalized mouse hepatocyte cultures. J Virol 76, 56465653.

Rang, A., Gunther, S., Will, H., 1999. Effect of interferon alpha on hepatitis B virus replication and gene expression in transiently transfected human hepatoma cells. J Hepatol 31, 791-799.

Rehermann, B., Bertoletti, A., 2015. Immunological aspects of antiviral therapy of chronic hepatitis $B$ virus and hepatitis $C$ virus infections. Hepatology $61,712-721$. 
Reizis, B., Bunin, A., Ghosh, H.S., Lewis, K.L., Sisirak, V., 2011. Plasmacytoid Dendritic Cells: Recent Progress and Open Questions. Annu. Rev. Immunol. 29, 163-183.

Robek, M.D., Boyd, B.S., Chisari, F.V., 2005. Lambda interferon inhibits hepatitis B and C virus replication. J Virol 79, 3851-3854.

Roff, S.R., Noon-Song, E.N., Yamamoto, J.K., 2014. The Significance of Interferon-gamma in HIV-1 Pathogenesis, Therapy, and Prophylaxis. Frontiers in immunology 4, 498.

Saade, F., Buronfosse, T., Guerret, S., Pradat, P., Chevallier, M., Zoulim, F., Jamard, C., Cova, L., 2013. In vivo infectivity of liver extracts after resolution of hepadnaviral infection following therapy associating DNA vaccine and cytokine genes. J. Viral Hepat. 20, e56-e65.

Sadler, A.J., Williams, B.R.G., 2008. Interferon-inducible antiviral effectors. Nat Rev Immunol 8, 559-568.

Samuel, C.E., 2001. Antiviral actions of interferons. Clinical microbiology reviews 14, 778-809, table of contents.

Schoggins, J.W., Wilson, S.J., Panis, M., Murphy, M.Y., Jones, C.T., Bieniasz, P., Rice, C.M., 2011. A diverse range of gene products are effectors of the type I interferon antiviral response. Nature 472, 481-485.

Seeger, C., Zoulim, F., Mason, W.S., 2015. Hepadnaviruses, in: Knipe, D.M., Howley, P.M. (Eds.), Field's Virology. Lippincott Williams \& Wilkins, Philadelphia, p. 2185.

Smith, N.L.D., Denning, D.W., 2014. Clinical implications of interferon- $\gamma$ genetic and epigenetic variants. Immunology 143, 499-511.

Snell, L.M., Brooks, D.G., 2015. New insights into type I interferon and the immunopathogenesis of persistent viral infections. Current Opinion in Immunology 34, 91-98.

Subramanian, G.M., Fiscella, M., Lamouse-Smith, A., Zeuzem, S., McHutchison, J.G., 2007. Albinterferon alpha-2b: a genetic fusion protein for the treatment of chronic hepatitis $C$. Nature biotechnology 25, 1411-1419.

Szabo, G., Petrasek, J., 2015. Inflammasome activation and function in liver disease. Nat Rev Gastroenterol Hepatol advance online publication.

Taylor, J.S., Zhang, Q., Julander, J.G., Stoycheva, A.D., Tan, H., Moy, C.V., Chanda, S., Symons, J.A., Beigelman, L.N., Blatt, L.M., Hong, J., 2015. Development of a Hyperglycosylated IFN Alfacon-1 (CIFN): Toward Bimonthly or Monthly Dosing for Antiviral Therapies. Journal of interferon \& cytokine research : the official journal of the International Society for Interferon and Cytokine Research.

Thimme, R., Dandri, M., 2013. Dissecting the divergent effects of interferon-alpha on immune cells: time to rethink combination therapy in chronic hepatitis B? J. Hepatol. 58, 205-209.

Tunçbilek, S., 2014. Relationship between cytokine gene polymorphisms and chronic hepatitis B virus infection. World J. Gastroenterol. 20, 6226-6235.

Tzeng, H.-T., Tsai, H.-F., Liao, H.-J., Lin, Y.-J., Chen, L., Chen, P.-J., Hsu, P.-N., 2012. PD-1 Blockage Reverses Immune Dysfunction and Hepatitis B Viral Persistence in a Mouse Animal Model. PLOS ONE 7, e39179.

Ulland, T.K., Ferguson, P.J., Sutterwala, F.S., 2015. Evasion of inflammasome activation by microbial pathogens. J Clin Invest 125, 469-477.

van der Aa, E., van Montfoort, N., Woltman, A.M., 2015. BDCA3+CLEC9A+ human dendritic cell function and development. Seminars in Cell \& Developmental Biology 41, 39-48.

Verstrepen, L., Bekaert, T., Chau, T.L., Tavernier, J., Chariot, A., Beyaert, R., 2008. TLR-4, IL-1R and TNF-R signaling to NF- $\kappa$ B: variations on a common theme. Cell. Mol. Life Sci. 65, 2964-2978.

Visvanathan, K., Skinner, N.A., Thompson, A.J., Riordan, S.M., Sozzi, V., Edwards, R., Rodgers, S., Kurtovic, J., Chang, J., Lewin, S., Desmond, P., Locarnini, S., 2007. Regulation of Toll-like receptor-2 expression in chronic hepatitis B by the precore protein. Hepatology 45, 102-110. 
Watashi, K., Liang, G., Iwamoto, M., Marusawa, H., Uchida, N., Daito, T., Kitamura, K., Muramatsu, M., Ohashi, H., Kiyohara, T., Suzuki, R., Li, J., Tong, S., Tanaka, Y., Murata, K., Aizaki, H., Wakita, T., 2013. Interleukin-1 and tumor necrosis factor- $\alpha$ trigger restriction of hepatitis $B$ virus infection via a cytidine deaminase activation-induced cytidine deaminase (AID). J. Biol. Chem. 288, 31715-31727.

Wedemeyer, H., Yurdaydin, C., Dalekos, G.N., Erhardt, A., Cakaloglu, Y., Degertekin, H., Gurel, S., Zeuzem, S., Zachou, K., Bozkaya, H., Koch, A., Bock, T., Dienes, H.P., Manns, M.P., Group, H.S., 2011. Peginterferon plus adefovir versus either drug alone for hepatitis delta. The New England journal of medicine 364, 322-331.

Weng, H.-L., Wang, B.-E., Jia, J.-D., Wu, W.-F., Xian, J.-Z., Mertens, P.R., Cai, W.-M., Dooley, S., 2005. Effect of Interferon-Gamma on Hepatic Fibrosis in Chronic Hepatitis B Virus Infection: A Randomized Controlled Study. Clinical Gastroenterology and Hepatology 3, 819-828.

Wieland, S.F., Guidotti, L.G., Chisari, F.V., 2000. Intrahepatic induction of alpha/beta interferon eliminates viral RNA-containing capsids in hepatitis B virus transgenic mice. J. Virol. 74, 41654173.

Wolchok, J.D., Kluger, H., Callahan, M.K., Postow, M.A., Rizvi, N.A., Lesokhin, A.M., Segal, N.H., Ariyan, C.E., Gordon, R.-A., Reed, K., Burke, M.M., Caldwell, A., Kronenberg, S.A., Agunwamba, B.U., Zhang, X., Lowy, I., Inzunza, H.D., Feely, W., Horak, C.E., Hong, Q., Korman, A.J., Wigginton, J.M., Gupta, A., Sznol, M., 2013. Nivolumab plus Ipilimumab in Advanced Melanoma. New England Journal of Medicine 369, 122-133.

Xia, Y.C., Lucifora, J., Reisinger, F., Heikenwalder, M., Protzer, U., 2014. VIROLOGY Response to Comment on "Specific and nonhepatotoxic degradation of nuclear hepatitis B virus cccDNA". Science 344, 1.

Yang, F.Q., Yu, Y.Y., Wang, G.Q., Chen, J., Li, J.H., Li, Y.Q., Rao, G.R., Mo, G.Y., Luo, X.R., Chen, G.M., 2012. A pilot randomized controlled trial of dual-plasmid HBV DNA vaccine mediated by in vivo electroporation in chronic hepatitis B patients under lamivudine chemotherapy. J. Viral Hepat. 19, 581-593.

Ye, B., Liu, X., Li, X., Kong, H., Tian, L., Chen, Y., 2015. T-cell exhaustion in chronic hepatitis B infection: current knowledge and clinical significance. Cell death \& disease 6, e1694.

Zannetti, C., Isorce, N., Roblot, G., Luangsay, S., Rozieres, A., Gruffaz, M., Briat, F., Zoulim, F., Henry, T., Durantel, D., Hasan, U.A., 2013. HBV INHIBITS THE AIM-2 INFLAMMASOME IN HUMAN KUPFFER CELLS. J. Hepatol. 58, S140-S140.

Zeuzem, S., Sulkowski, M.S., Lawitz, E.J., Rustgi, V.K., Rodriguez-Torres, M., Bacon, B.R., Grigorescu, M., Tice, A.D., Lurie, Y., Cianciara, J., Muir, A.J., Cronin, P.W., Pulkstenis, E., Subramanian, G.M., McHutchison, J.G., Team, A.-S., 2010. Albinterferon Alfa-2b was not inferior to pegylated interferon-alpha in a randomized trial of patients with chronic hepatitis $C$ virus genotype 1. Gastroenterology 139, 1257-1266.

Zhang, X., Ma, Z., Liu, H., Liu, J., Meng, Z., Broering, R., Yang, D., Schlaak, J.F., Roggendorf, M., Lu, M., 2012. Role of Toll-like receptor 2 in the immune response against hepadnaviral infection. J. Hepatol. 57, 522-528.

Zheng, Y., Zhao, L., Wu, T., Guo, S., Chen, Y., Zhou, T., 2009. Efficacy of consensus interferon in treatment of $\mathrm{HbeAg}$-positive chronic hepatitis $\mathrm{B}$ : a multicentre, randomized controlled trial. Virology journal 6, 99.

Zitvogel, L., Galluzzi, L., Kepp, O., Smyth, M.J., Kroemer, G., 2015. Type I interferons in anticancer immunity. Nat Rev Immunol advance online publication.

Zoulim, F., Durantel, D., 2015. Antiviral therapies and prospects for a cure of chronic hepatitis B. Cold Spring Harbor perspectives in medicine 5.

9. 


\section{Figure legends}

Figure 1. Interferon signaling pathways. Type I, II, or III IFNs interact with their respective receptors and trigger downstream signaling pathways leading to the translocation of transcription factors capable of binding to specific sequences in promoters to induce gene expression. ISRE, IFN-stimulated response element; GAS, IFN- $\gamma$ activation sites.

Figure 2. Pro-inflammatory cytokine signaling pathways. IL-6, TNF- $\alpha$, or IL-1 $\beta$ interact with their respective receptors and trigger downstream signaling pathways leading to the translocation of transcription factors capable of binding to specific sequences in promoters to induce gene expression. NF$\kappa \mathrm{B}$, binding site for NF- $\mathrm{KB}$ transcription factor; AP1, binding site for $\mathrm{CFos/cJun} \mathrm{(AP1)} \mathrm{transcription} \mathrm{factor;}$ STAT3-RE, STAT3 response element.

Figure 3. Endogenous pathways of production and action of IL-1 $\beta$. Upon a bimodal activation (TLR and Aim2 inflammasome), IL-1 $\beta$ can be produced by Kupffer cells, and can then act on infected hepatocytes, leading to the inhibition of HBV replication by first inducing the silencing of cccDNA, then its degradation via a mechanism involving likely APOBEC3B. However, HBV is capable of blocking the production of IL-1 $\beta$ from macrophages/Kupffer cells by molecular mechanisms which are yet to be uncovered. Therefore, strategies aiming at unlocking HBV-mediated inhibition or inducing the production of IL-1b, despite the presence of $\mathrm{HBV}$, would be an interesting immune-therapeutic approach.

Figure 4. Mechanism of antiviral action of various drugs or investigational molecules. While nucleoside analogues lead only to the suppression of circulating HBV virions, IFN- $\alpha$ and IL-1 $\beta$, when used the right concentrations, can also prevent the production of all kind of HBV particles and HBV antigens. Long-term exposure to either IFN- $\alpha$, a LT- $\beta$ R agonist or IL- $1 \beta$ can also induce the degradation of $\operatorname{cccDNA}$, which is the main template of HBV transcription. Such a strategy can lead to the eradication of HBV from an infected cells, and represent a new exploratory avenue for novel therapeutic developments. 


\begin{tabular}{|c|c|c|c|}
\hline $\begin{array}{l}\text { Commercial } \\
\text { name }\end{array}$ & Molecule & Manufacturer & Indications \\
\hline Roferon A & IFN- $\alpha 2 a$ & $\begin{array}{l}\text { Hoffmann-La- } \\
\text { Roche }\end{array}$ & $\begin{array}{l}\text { Chronic hepatitis B and C; } \\
\text { leukemia (CML and } \mathrm{HCL}) \text {, Kaposi's } \\
\text { sarcoma }\end{array}$ \\
\hline Intron A & IFN- $\alpha 2 b$ & Merck & $\begin{array}{l}\text { Chronic hepatitis B and C; some } \\
\text { cancers }\end{array}$ \\
\hline Pegasys & Peg-IFN- $\alpha 2 a$ & $\begin{array}{l}\text { Hoffmann-La- } \\
\text { Roche }\end{array}$ & $\begin{array}{l}\text { Chronic hepatitis B and C; } \\
\text { coinfection with HIV }\end{array}$ \\
\hline Peg-Intron & Peg-IFN- $\alpha 2 b$ & Merck & $\begin{array}{l}\text { Chronic hepatitis B and C; } \\
\text { coinfection with HIV }\end{array}$ \\
\hline Infergen & IFN-alphacon-1 & InterMune & $\begin{array}{l}\text { Chronic hepatitis C; leukemia (CML } \\
\text { and } \mathrm{HCL} \text { ), Kaposi's sarcoma }\end{array}$ \\
\hline Alferon $\mathbf{N}$ & IFN- $\alpha$ n3 & $\begin{array}{l}\text { Hemispherx } \\
\text { Biopharma }\end{array}$ & $\begin{array}{l}\text { Genital and perianal warts caused } \\
\text { by human papillomavirus (HPV) }\end{array}$ \\
\hline Rebif & IFN- $\beta 1 \mathrm{a}$ & Merck-Serono & Multiple sclerosis \\
\hline Avonex & IFN- $\beta 1 a$ & Biogen & $\begin{array}{l}\text { Multiple sclerosis; lymphoma (in } \\
\text { some countries) }\end{array}$ \\
\hline Extavia & IFN- $\beta 1 b$ & Novartis & Multiple sclerosis \\
\hline \multirow[t]{2}{*}{ Betaseron } & IFN- $\beta 1 b$ & Bayer & Multiple sclerosis \\
\hline & Peg-IFN & BMS & $\begin{array}{l}\text { In clinical trial for chronic hepatitis } \\
\text { C }\end{array}$ \\
\hline Imukin & IFN- $\gamma 1 b$ & $\begin{array}{l}\text { Boehringer } \\
\text { Ingelheim }\end{array}$ & $\begin{array}{l}\text { Chronic granulomatous disease; } \\
\text { severe, malignant Osteopetrosis }\end{array}$ \\
\hline Actimmune & IFN- $\gamma 1 b$ & Horizon Pharma & $\begin{array}{l}\text { Chronic granulomatous disease; } \\
\text { severe, malignant Osteopetrosis }\end{array}$ \\
\hline Proleukin & IL-2 & Prometheus & $\begin{array}{l}\text { Metastatic cancer (melanoma, } \\
\text { kidney...) }\end{array}$ \\
\hline Cyt107 & IL-7 & Cytheris & $\begin{array}{l}\text { Progressive multifocal } \\
\text { leukoencephalopathy }\end{array}$ \\
\hline Oprelvekin & IL-11 & Pfizer & $\begin{array}{l}\text { Prevention of severe reductions of } \\
\text { platelet number caused by } \\
\text { chemotherapies }\end{array}$ \\
\hline
\end{tabular}

Table 1. Interferons and cytokines/chemokines used in the clinic. 


\begin{tabular}{|c|c|c|c|}
\hline Molecules & $\begin{array}{l}\text { HBV life cycle steps } \\
\text { targeted }\end{array}$ & Study models & References \\
\hline IFN- $\alpha$ & $\begin{array}{l}\text { - } \\
\text { - } \text { cccDnAapsidation } \\
\text { - } \\
\text { cccDNA } \\
\text { degradationcing }\end{array}$ & $\begin{array}{ll}\text { - } & \text { Hepatoma cell } \\
& \text { lines } \\
\text { - } & \text { dHepaRG } \\
\text { - } & \text { PHH } \\
\text { - } & \text { HuHep mice }\end{array}$ & $\begin{array}{l}\text { Gordien et al., 2001; Mao et } \\
\text { al., 2013; Nguyen et al., 2007; } \\
\text { Belloni et al., 2012; Rang et } \\
\text { al., 1999; Wieland et al., } \\
\text { 2000; Lucifora, Xia et al., } \\
\text { 2014 ; Allweiss et al., 2014. }\end{array}$ \\
\hline IFN- $\beta$ & $\begin{array}{l}\text { - Destabilization of } \\
\text { pgRNA containing } \\
\text { capsids }\end{array}$ & $\begin{array}{ll}\text { - } & \text { Hepatoma cell } \\
& \text { lines } \\
\text { - } & \text { dHepaRG } \\
\text { - } & \text { HBV-transgenic } \\
& \text { mice }\end{array}$ & $\begin{array}{l}\text { Guidotti et al., 1996a; } \\
\text { Guidotti et al., 1994; Isogawa } \\
\text { et al., 2005; Pasquetto et al., } \\
\text { 2000; Pasquetto et al., 2002; } \\
\text { Wieland et al., } 2000 .\end{array}$ \\
\hline IFN- $\lambda$ & - As for type-I IFN? & $\begin{array}{ll}\text { - } & \text { dHepaRG } \\
\text { - } & \text { PHH } \\
\text { - } & \text { HuHep mice }\end{array}$ & $\begin{array}{l}\text { Robeck et al., 2005; Isorce et } \\
\text { al., submitted; AVR-S-15- } \\
\text { 00187; Nakagawa et al., } \\
2013 .\end{array}$ \\
\hline IFN- $\boldsymbol{Y}$ & $\begin{array}{ll}\text { - } & \text { pgRNA stability } \\
\text { - } & \text { Encapsidation } \\
\text { - } & \text { cccDNA } \\
& \text { degradation }\end{array}$ & $\begin{array}{l}\text { - } \text { dHepaRG } \\
\text { - } \text { PHH } \\
\text { - } \text { HBV-transgenic } \\
\text { mice }\end{array}$ & $\begin{array}{l}\text { Guidotti et al., 2002; Isorce et } \\
\text { al., submitted; AVR-S-15- } \\
00187 .\end{array}$ \\
\hline TNF- $\alpha$ & $\begin{array}{l}\text { - Destabilization of } \\
\text { pgRNA containing } \\
\text { capsids } \\
\text { - cccDNA } \\
\text { degradation }\end{array}$ & $\begin{array}{ll}\text { - } & \text { Hepatoma cell } \\
& \text { lines } \\
\text { - } & \text { dHepaRG } \\
\text { - } & \text { PHH } \\
\text { - } & \text { HBV-transgenic } \\
& \text { mice }\end{array}$ & $\begin{array}{l}\text { Kawanishi et al., 1995; } \\
\text { Guidotti et al., 1999; Heise et } \\
\text { al., 1999; Pasquetto et al., } \\
\text { 2002; Watashi et al., 2013; } \\
\text { Isorce et al., submitted; AVR- } \\
\text { S-15-00187. }\end{array}$ \\
\hline IL-6 & $\begin{array}{ll}\text { - } & \text { HBV mRNA } \\
\text { transcription } \\
\text { - } & \text { Entry }\end{array}$ & $\begin{array}{ll}\text { - } & \text { PHH } \\
\text { - } & \mathrm{dHepaRG}\end{array}$ & $\begin{array}{l}\text { Hösel et al., 2009; } \\
\text { Bouezzedine et al., } 2015 .\end{array}$ \\
\hline IL-1 $\beta$ & $\begin{array}{ll}\text { - } & \text { cccDNA silencing } \\
\text { - } & \text { HBV mRNA } \\
\text { transcription } \\
\text { - } \\
\text { cccDNA } \\
\text { degradation }\end{array}$ & $\begin{array}{l}\text { - } \mathrm{dHepaRG} \\
\text { - } \mathrm{PHH}\end{array}$ & $\begin{array}{l}\text { Watashi et al., 2013; Isorce et } \\
\text { al., submitted; AVR-S-15- } \\
00187 .\end{array}$ \\
\hline $\begin{array}{l}\text { IL-2, IL-12, } \\
\text { IL-18 }\end{array}$ & $\begin{array}{l}\text { - Immune } \\
\text { stimulation }\end{array}$ & $\begin{array}{l}\text { - HBV-transgenic } \\
\text { mice }\end{array}$ & $\begin{array}{l}\text { Cavanaugh et al., 1997; } \\
\text { Guidotti et al., 1994; Kimura } \\
\text { et al., } 2002 .\end{array}$ \\
\hline $\begin{array}{l}\text { LTßR- } \\
\text { agonists }\end{array}$ & $\begin{array}{ll}\text { - } & \text { HBV mRNA } \\
& \text { transcription } \\
- & \text { cccDNA } \\
& \text { degradation }\end{array}$ & $\begin{array}{ll}\text { - } & \text { dHepaRG } \\
\text { - } & \text { PHH } \\
\text { - } & \text { HBV-transgenic } \\
& \text { mice } \\
\text { - } & \text { HuHep mice }\end{array}$ & Lucifora, Xia et al., 2014. \\
\hline
\end{tabular}




\begin{tabular}{|c|c|c|c|}
\hline $\begin{array}{l}\text { TLR7- } \\
\text { agonist }\end{array}$ & $\begin{array}{l}\text { - } \quad \text { cccDNA silencing? } \\
\text { - } \text { HBV mRNA } \\
\text { transcription? } \\
\text { - cccDNA } \\
\text { degradation? }\end{array}$ & $\begin{array}{l}\text { - HBV-infected } \\
\text { chimpanzees } \\
\text { - WHV-infected } \\
\text { woodchuck }\end{array}$ & $\begin{array}{l}\text { Lanford et al., 2013; Menne } \\
\text { et al., } 2015 .\end{array}$ \\
\hline
\end{tabular}

Table 2. In vitro and animal studies using various IFNs and cytokines/chemokined. 
Figure 1

\section{Type I IFNs}

IFN- $\alpha$, IFN- $\beta$, IFN- $\varepsilon$,

IFN-K, IFN- $\omega$

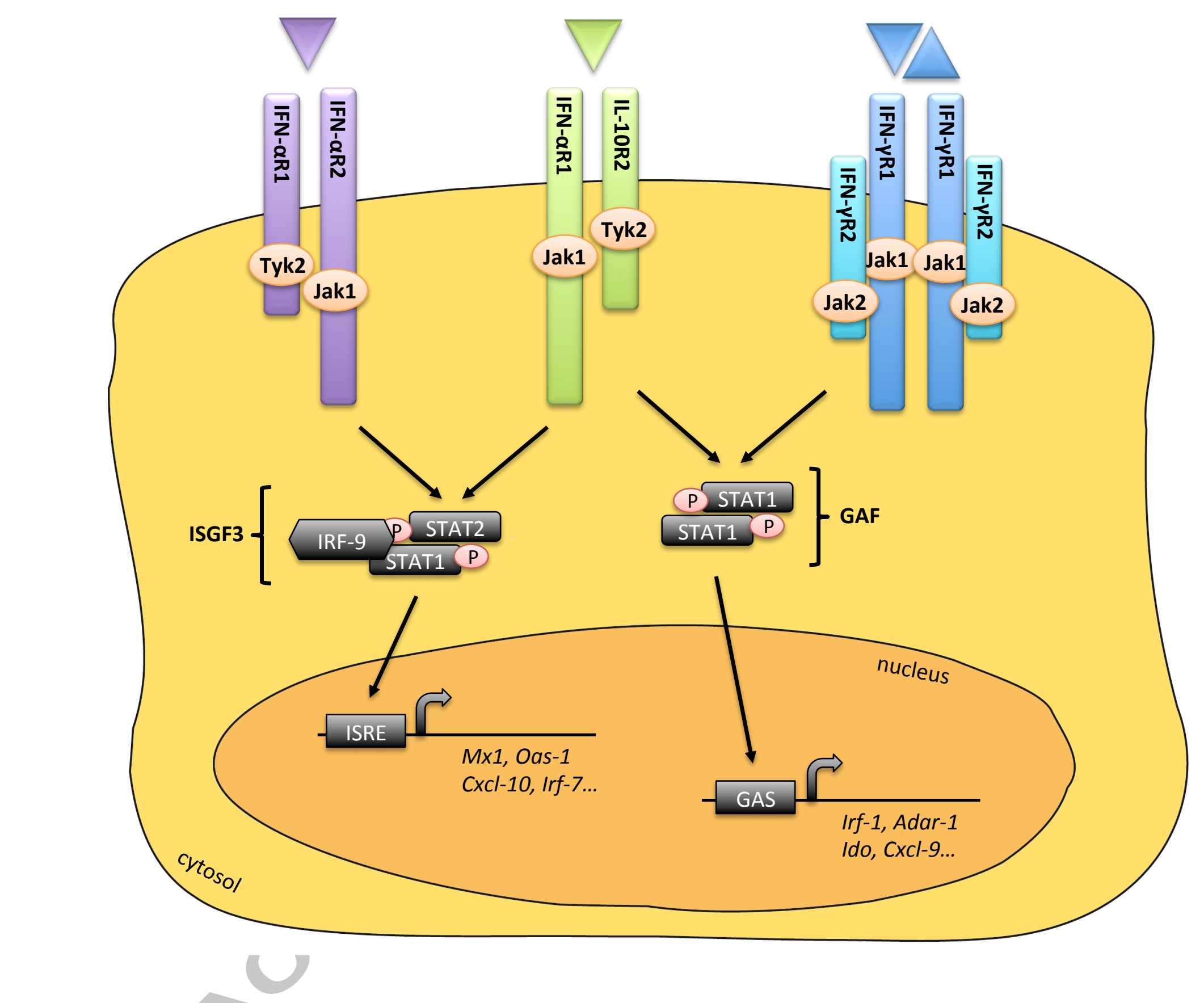

Type III IFNs

IFN- $\lambda 1$, IFN- $\lambda 2$,

IFN- $\lambda 3$
Type II IFN

IFN- $\gamma$ 


\section{Figure 2}

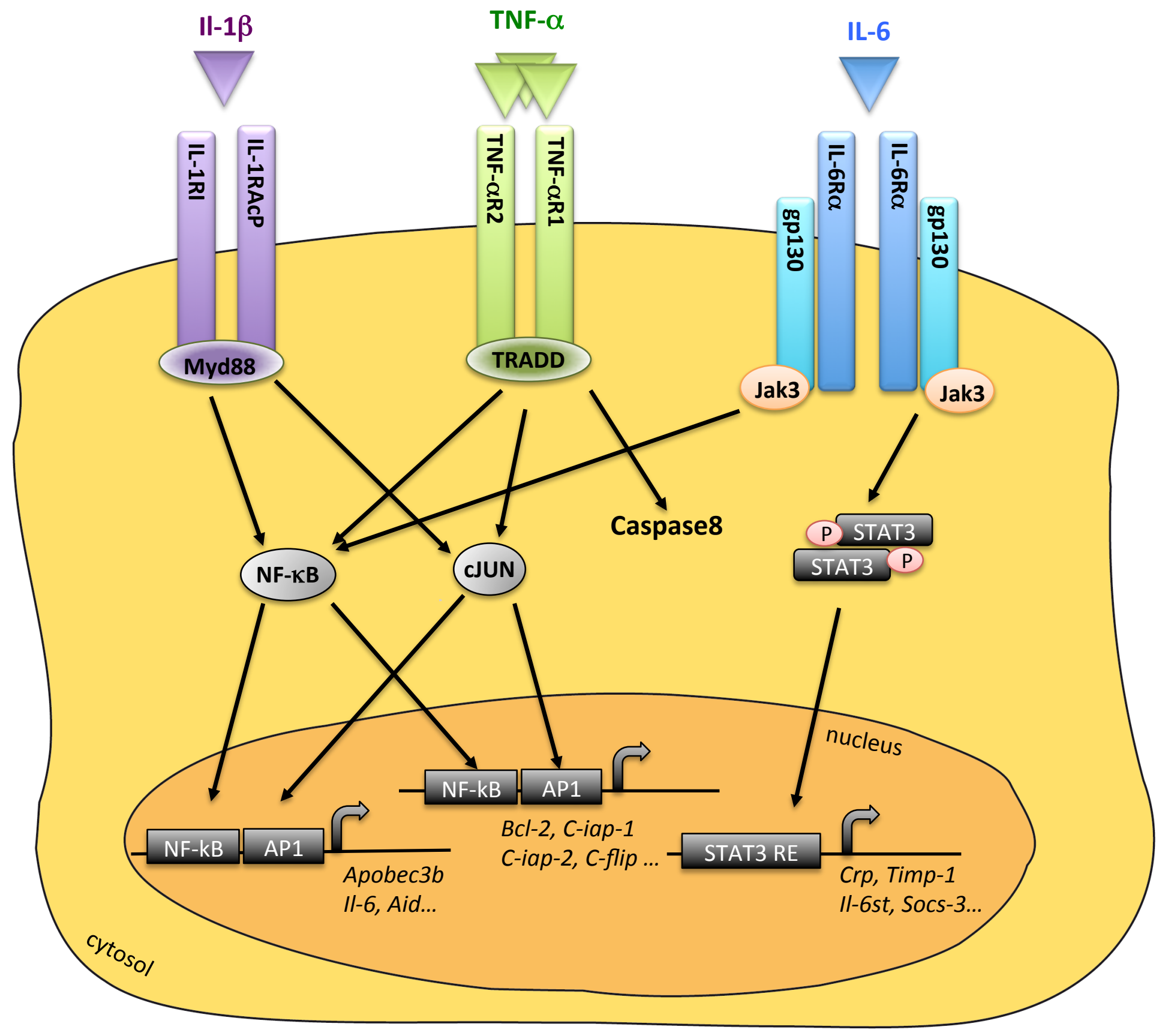


Figure 3

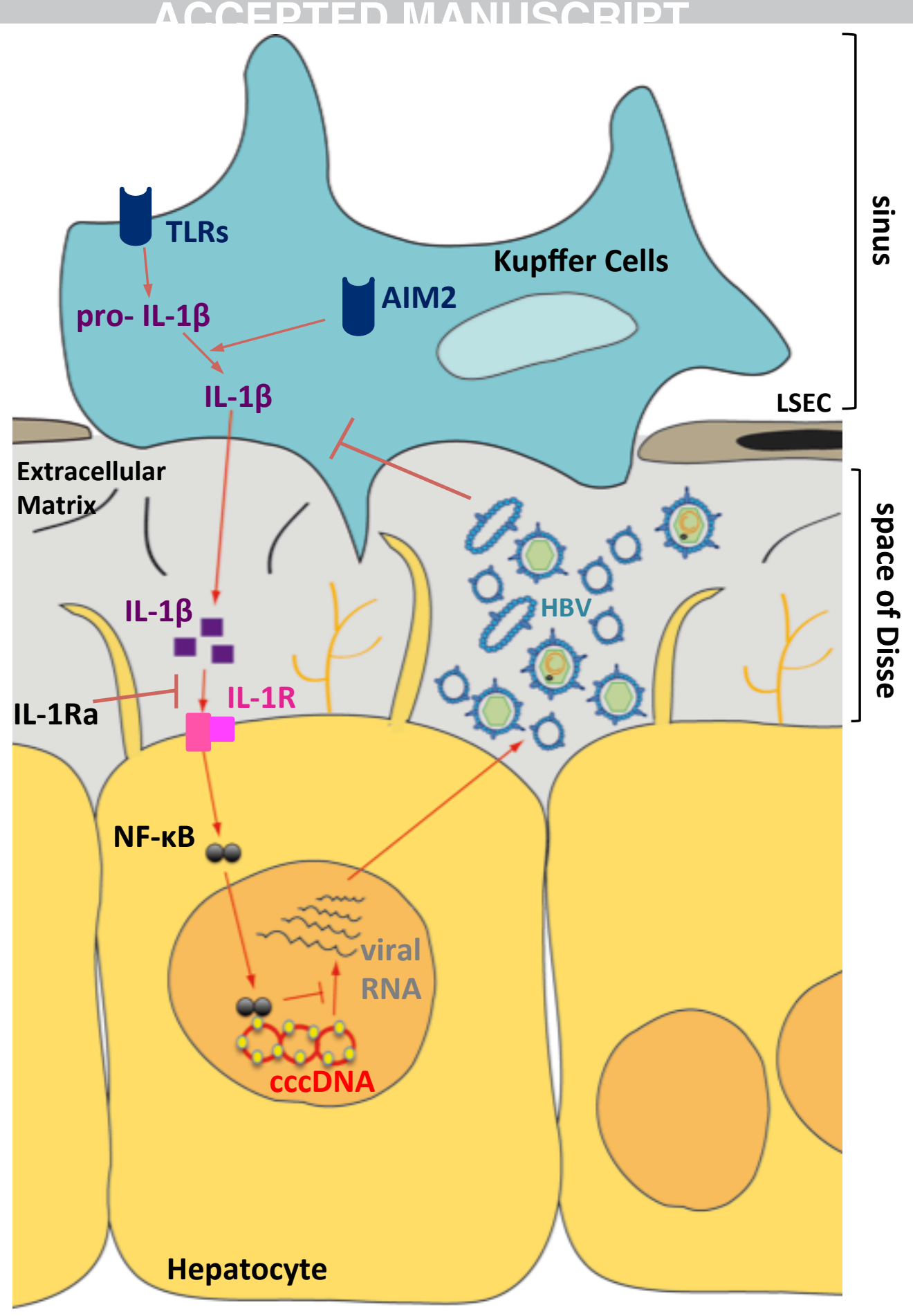


Figure 4

A

C

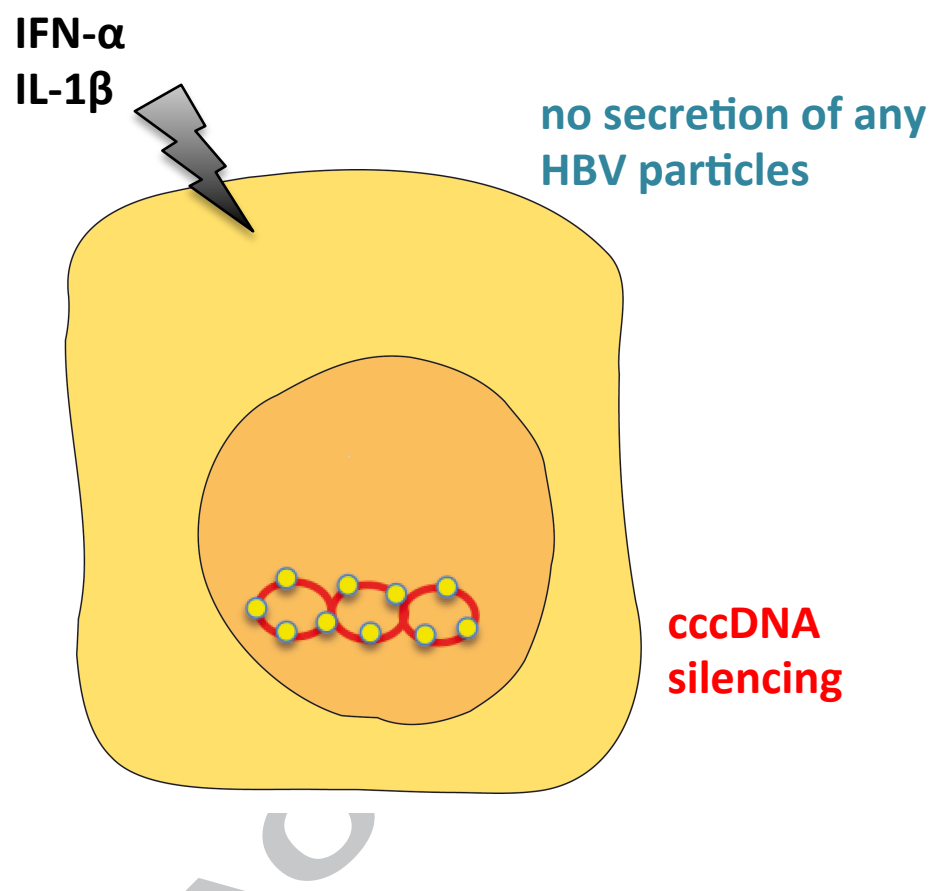

HBV particles no treatment

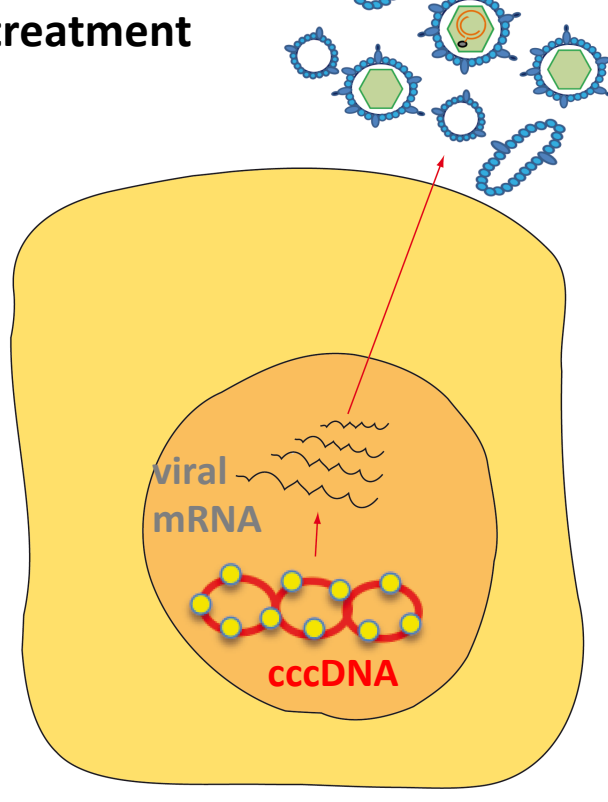

B

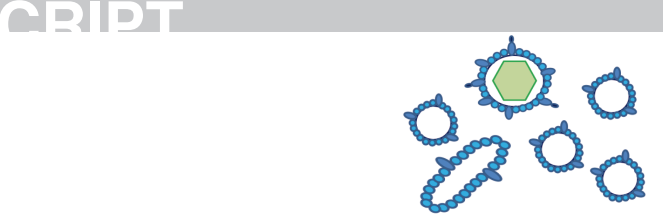

D

NUC Dane particles (i.e. virions)

IFN- $\alpha$

IL-1 $\beta$

LT $\beta R$-agonists

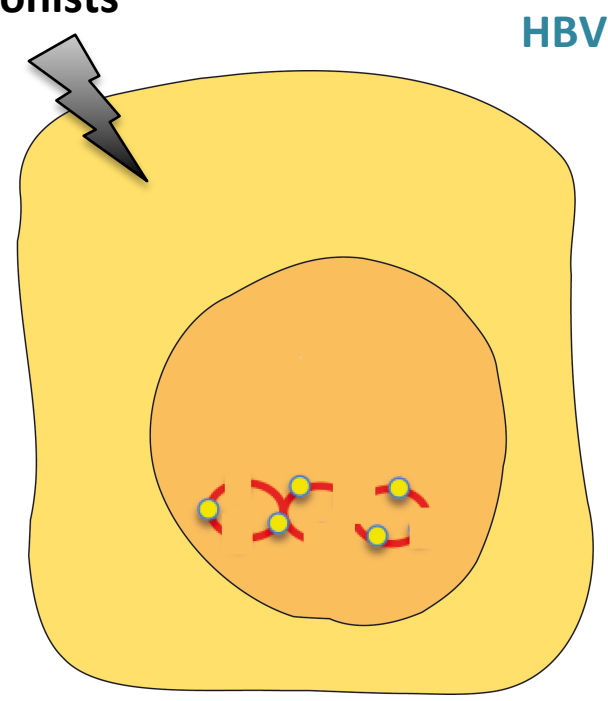

cccDNA degradation no effect

on ccCDNA 


\section{ISORCE Highlights Bray edits 8 Aug 15:}

- Interferon- $\alpha$ (IFN- $\alpha$ ) and its pegylated form are used as "front line" therapy to treat patients with chronic hepatitis $B$.

- IFN- $\alpha$-based therapies result in "HBeAg to anti-HBeAg" seroconversion in about $30 \%$ of cases.

- The same therapies result in "HBsAg to anti-HBsAg" seroconversion in about 3\% of cases.

- New immune-modulator strategies are needed to restore endogenous production of IFN- $\alpha$ and other cytokines/chemokines.

- Basic research is also needed to better understand the interplay between hepatitis B virus (HBV) and the immune system. 